\title{
Demethylation of G-Protein-Coupled Receptor 151 Promoter Facilitates the Binding of Krüppel-Like Factor 5 and Enhances Neuropathic Pain after Nerve Injury in Mice
}

\author{
Boo-Chun Jiang, ${ }^{1 *}$ Wen-Wen Zhang, ${ }^{1 *}$ Tian Yang, ${ }^{1 *}{ }^{\circledR C}$ Chang-Yun Guo, ${ }^{1}$ De-Li Cao, ${ }^{1}$ ¿Zhi-Jun Zhang, ${ }^{1,2}$ \\ and $\odot$ Yong-Jing Gao ${ }^{1,3}$ \\ ${ }^{1}$ Pain Research Laboratory, Institute of Nautical Medicine, Nantong University, Jiangsu 226019, China, ${ }^{2}$ Department of Human Anatomy, School of \\ Medicine, Nantong University, Jiangsu 226001, China, and ${ }^{3}$ Co-Innovation Center of Neuroregeneration, Nantong University, Jiangsu 226001, China
}

G-protein-coupled receptors are considered to be cell-surface sensors of extracellular signals, thereby having a crucial role in signal transduction and being the most fruitful targets for drug discovery. G-protein-coupled receptor 151 (GPR151) was reported to be expressed specifically in the habenular area. Here we report the expression and the epigenetic regulation of GRP151 in the spinal cord after spinal nerve ligation (SNL) and the contribution of GPR151 to neuropathic pain in male mice. SNL dramatically increased GPR151 expression in spinal neurons. GPR151 mutation or spinal inhibition by shRNA alleviated SNL-induced mechanical allodynia and heat hyperalgesia. Interestingly, the CpG island in the GPR151 gene promoter region was demethylated, the expression of DNA methyltransferase $3 \mathrm{~b}$ (DNMT3b) was decreased, and the binding of DNMT3b with GPR151 promoter was reduced after SNL. Overexpression of DNMT3b in the spinal cord decreased GPR151 expression and attenuated SNL-induced neuropathic pain. Furthermore, Krüppel-like factor 5 (KLF5), a transcriptional factor of the KLF family, was upregulated in spinal neurons, and the binding affinity of KLF5 with GPR151 promoter was increased after SNL. Inhibition of KLF5 reduced GPR151 expression and attenuated SNL-induced pain hypersensitivity. Further mRNA microarray analysis revealed that mutation of GPR151 reduced the expression of a variety of pain-related genes in response to SNL, especially mitogen-activated protein kinase (MAPK) signaling pathway-associated genes. This study reveals that GPR151, increased by DNA demethylation and the enhanced interaction with KLF5, contributes to the maintenance of neuropathic pain via increasing MAPK pathway-related gene expression.

Key words: DNA methylation; DNMT3b; epigenetic; GPR151; KLF5; neuropathic pain

Significance Statement

G-protein-coupled receptors (GPCRs) are targets of various clinically approved drugs. Here we report that SNL increased GPR151 expression in the spinal cord, and mutation or inhibition of GPR151 alleviated SNL-induced neuropathic pain. In addition, SNL downregulated the expression of DNMT3b, which caused demethylation of GPR151 gene promoter, facilitated the binding of transcriptional factor KLF5 with the GPR151 promoter, and further increased GPR151 expression in spinal neurons. The increased GPR151 may contribute to the pathogenesis of neuropathic pain via activating MAPK signaling and increasing pain-related gene expression. Our study reveals an epigenetic mechanism underlying GPR151 expression and suggests that targeting GPR151 may offer a new strategy for the treatment of neuropathic pain.

\section{Introduction}

G-protein-coupled receptors (GPCRs) are a superfamily of cellsurface receptors that sense various extracellular signals includ-

Received March 15, 2018; revised Sept. 13, 2018; accepted 0ct. 22, 2018

Author contributions: B.-C.J. wrote the first draft of the paper; Y.-J.G. edited the paper; Y.-J.G. designed research; B.-C.J., W.-W.Z., T.Y., C.-Y.G., D.-L.C., and Z.-J.Z. performed research; B.-C.J., W.-W.Z., T.Y., and Y.-J.G. analyzed data; Y.-J.G. wrote the paper.

This work was supported by Grants from the National Natural Science Foundation of China (NSFC 81400915, $81771197,31671091,81571070,31700899$, and 31871064), and the Natural Science Foundation of Jiangsu Province (BK20171255, BK20140427). We thank Yu-Qiang Ding for providing GAD67-GFP ${ }^{+}$mice. ing neurotransmitters, hormones, and growth factors, and ultimately resulting in the activation of intracellular signaling pathways (Hauser et al., 2018). Of the druggable molecules in the human genome, GPCRs are the targets of $\sim 40 \%$ of clinically

The authors declare no competing financial interests.

${ }^{*}$ B.-C.J., W.-W.Z., and T.Y. contributed equally to this work.

Correspondence should be addressed to Yong-Jing Gao, Institute of Nautical Medicine, Nantong University, 9 Seyuan Road, Nantong, Jiangsu 226019, China. E-mail: gaoyongjing@hotmail.com.

https://doi.org/10.1523/JNEUROSCI.0702-18.2018

Copyright $\odot 2018$ the authors $\quad 0270-6474 / 18 / 3810535-17 \$ 15.00 / 0$ 
approved drugs (Buchen, 2012). Orphan GPCRs (oGPCRs) are a group of GPCRs whose endogenous ligands have not yet been identified. Unraveling the biological functions of oGPCRs will help to understand the physiological and pathological processes and to identify new potential drug targets.

GPR151 is one of oGPCRs, with its gene map to chromosome 5 q32 in human and to $18 \mathrm{~B} 3$ in mice. The functions of GPR151 are mostly unknown as no endogenous or synthetic ligand for this receptor has been reported yet. GPR151 was originally identified as galanin receptor based on its amino acid sequence similarity with galanin receptors 2 and 3, but responds only very weakly to the neuropeptide galanin (Ignatov et al., 2004). Previous studies demonstrated that GPR151 is highly enriched in rodent medial and lateral habenula (Kobayashi et al., 2013; Broms et al., 2015) where it extensively projects to the interpeduncular nucleus, the rostromedial tegmental area, the rhabdoid nucleus, and the mesencephalic raphe nuclei (Broms et al., 2015). Moreover, the fibers overlap with cholinergic, substance P-ergic and glutamatergic markers (Broms et al., 2015). These findings suggest that GPR151 may be involved in habenula-related functions, such as depression, negative reward, decision-making, nicotine withdrawal, and pain (Broms et al., 2017). However, the expression and the role of GPR151 in other areas of the CNS remain largely unknown.

Peripheral sensitization in the dorsal root ganglion (DRG) and central sensitization in the spinal cord play an important role in the pathogenesis of neuropathic pain (von Hehn et al., 2012). Recent studies using mRNA microarray analysis showed that GPR151 mRNA was highly upregulated in the DRG after chronic constriction injury (CCI)-induced neuropathic pain (Reinhold et al., 2015) or burn injury-induced pain (Yin et al., 2016). GPR151 was also dramatically increased in the spinal cord after spinal nerve ligation (SNL)-induced neuropathic pain in mice (Jiang et al., 2015). These studies indicate that GPR151 in the DRG and spinal cord may be involved in neuropathic pain. However, Holmes et al. (2017) recently reported that deletion of GPR151 did not affect acute pain, inflammatory pain, and neuropathic pain behaviors.

Several lines of evidence indicate that gene expression is regulated by epigenetic mechanisms (Niederberger et al., 2017). DNA methylation is a main epigenetic mechanism that modulates the compact of chromatin and the repression of gene expression (Cedar and Bergman, 2012). DNA methyltransferases (DNMTs) are important in regulating DNA methylation and directly inhibit transcription by interfering with transcription factor binding (Lyko, 2018). Kruppel-like factors (KLFs) are a 17-member family of zinc finger-containing transcription factors (Moore et al., 2009). KLF7 is required for the development of a subset of nociceptive sensory neurons by specifically regulating TrkA gene expression (Lei et al., 2005). Specific inhibition of KLF6, KLF9, and KLF15 by intrathecal DNA decoys alleviated mechanical hypersensitivity in the spared nerve injury (SNI)- or CCI-induced neuropathic pain in rats (Mamet et al., 2017). The promoter region of the GPR151 gene contains five consensus binding motifs of KLF5. Whether GPR151 expression is regulated by DNA methylation and KLF5 under neuropathic pain condition has not been investigated.

In the present work, we provide evidence that SNL increased GPR151 expression in the spinal neurons, and mutation or knockdown of GPR151 alleviated SNL-induced neuropathic pain. Our results also demonstrate that GPR151 expression is regulated by DNMT3b-mediated DNA demethylation and KLF5-mediated increase of transcription. The mRNA microarray analysis further revealed that GPR151 might regulate neuropathic pain via the activation of mitogen-activated protein kinase (MAPK) signaling pathways, which has been demonstrated to play a vital role in the pathogenesis of chronic pain (Ji et al., 2009; Anand et al., 2011).

\section{Materials and Methods}

Animals and surgery. Adult ICR mice and C57BL/6 (male, 6-8 weeks; RRID:MGI:5656552) mice were purchased from the Experimental Animal Center of Nantong University. GPR $151^{-/-}$mice were generated by Cyagen (Cyagen Biosciences). The animals were maintained in SPF facilities on a $12 \mathrm{~h} \mathrm{light/dark} \mathrm{cycle} \mathrm{at} \mathrm{a} \mathrm{room} \mathrm{temperature} \mathrm{of} 22 \pm 1^{\circ} \mathrm{C}$ with ad libitum access to food and water. The experimental procedures were approved by the Animal Care and Use Committee of Nantong University and performed in accordance with guidelines of the International Association for the Study of Pain. To produce SNL, animals were anesthetized with isoflurane, and the L6 transverse process was removed to expose the L4 and L5 spinal nerve. The L5 spinal nerve was then isolated and tightly ligated with 6-0 silk thread (Jiang et al., 2016). For sham-operated mice, the L5 spinal nerve was exposed but not ligated.

Generation of TALEN-mediated GPR151 mutant mice. Transcription activator-like (TAL) effector nucleases (TALENs) were used to create GPR151 mutant mice (GenBank accession number of GPR151: NM181543.1). TALENs were designed to target exon 1 of GPR151 using the TALENdesigner software (TALEs-L: 5' -TGG AGG ACC ATC ATT CCG3'; Spacer: 5' -TCT CTC TTG ATG GCC GTG TGC-3'; TALEs-R: 5' TCC CAC GAG ACC CAC CAG-3'; Fig. 1A). TALEN mRNAs were generated by in vitro transcription and injected into fertilized eggs of C57BL/6. The binding of TALENs with the GPR151 genome loci induced a site-specific double-strand break (DSB) followed by non-homologous end joining (NHEJ) repair, resulting in the deletion of some bases (Fig. $1 A)$. The chimera mice were identified by DNA sequencing (primer: 5'-GCC GAC ACC AAT TCC AGC AAC-3'; Fig. 1B).

DNA extraction and genotyping. Approximately $3 \mathrm{~mm}$ of the mouse tails were cut, and DNA was extracted with the phenol-chloroform method. PCR was performed to identify wild-type (WT) or GPR151 mutant mice. The following primers were used (forward: 5' -TCC AAG GAC TGG AGG ACC AT-3' , reverse: 5' -CAC ACA GGT TTC CCA CGA GA-3'; WT: 76 bp, GPR151 ${ }^{-/-}: 69$ bp). For PCR amplification, $\sim 500 \mathrm{ng}$ DNA was used in a $50 \mu \mathrm{l}$ reaction volume containing $25 \mu \mathrm{l} 2 \times$ TaqPCR MasterMix (Tiangen Biotech) and $1 \mu \mathrm{M}$ primers. Reactions initially were denatured at $94^{\circ} \mathrm{C}$ for $3 \mathrm{~min}$ followed by 35 cycles at $94^{\circ} \mathrm{C}$ for $30 \mathrm{~s}, 60^{\circ} \mathrm{C}$ for $30 \mathrm{~s}, 72^{\circ} \mathrm{C}$ for $30 \mathrm{~s}$, and a final extension at $72^{\circ} \mathrm{C}$ for $2 \mathrm{~min}$. Amplicons were separated using $3 \%$ agarose gel, stained with DuRed (Biotium) and photographed with GelDoc-It Imaging System (UVP).

Drugs and administration. 5'-Cholesteryl and 2'-O-methyl-modified small interfering RNA (siRNA) for DNMT3b or KLF5, and an additional scrambled siRNA were purchased from RiboBio. A potent KLF5 inhibitor, ML264 was purchased from Selleck Chemicals. Intrathecal injection was made with a 30-G needle between the L5 and L6 level to deliver the reagents to the CSF.

Real-time PCR. The total RNA of L5 spinal cord was extracted using TRIzol reagent (Invitrogen; Life Technologies). One microgram total RNA was converted into cDNA through Prime ScriptTM RT reagent Kit (TaKaRa). PCRs were performed on a Light Cycler 96 RT-PCR system (Roche Diagnostics) using FastStart Essential DNA Green Master (Roche Diagnostics) for detecting. The primer sequences for each gene are listed in Table 1. The PCR amplifications were performed at $95^{\circ} \mathrm{C}$ for $600 \mathrm{~s}$, followed by 45 cycles of thermal cycling at $95^{\circ} \mathrm{C}$ for $10 \mathrm{~s}, 60^{\circ} \mathrm{C}$ for $10 \mathrm{~s}$, and $72^{\circ} \mathrm{C}$ for $10 \mathrm{~s}$. GAPDH was used as endogenous control to normalize differences. The data were analyzed through LightCycler96 software and evaluated using the comparative CT method $\left(2^{-\Delta \Delta \mathrm{CT}}\right)$.

Single-cell PCR. All the facilities used for single-cell PCR experiment were treated with DEPC before use. The reagents were prepared according to the instruction to remove the genomic DNA (Invitrogen). The single cell was collected in the mixture using glass electrode from the acute isolation of L5 spinal dorsal horn sections. The first step of reverse transcription system was performed at $37^{\circ} \mathrm{C}$ for $40 \mathrm{~min}$ and then at $80^{\circ} \mathrm{C}$ 
A
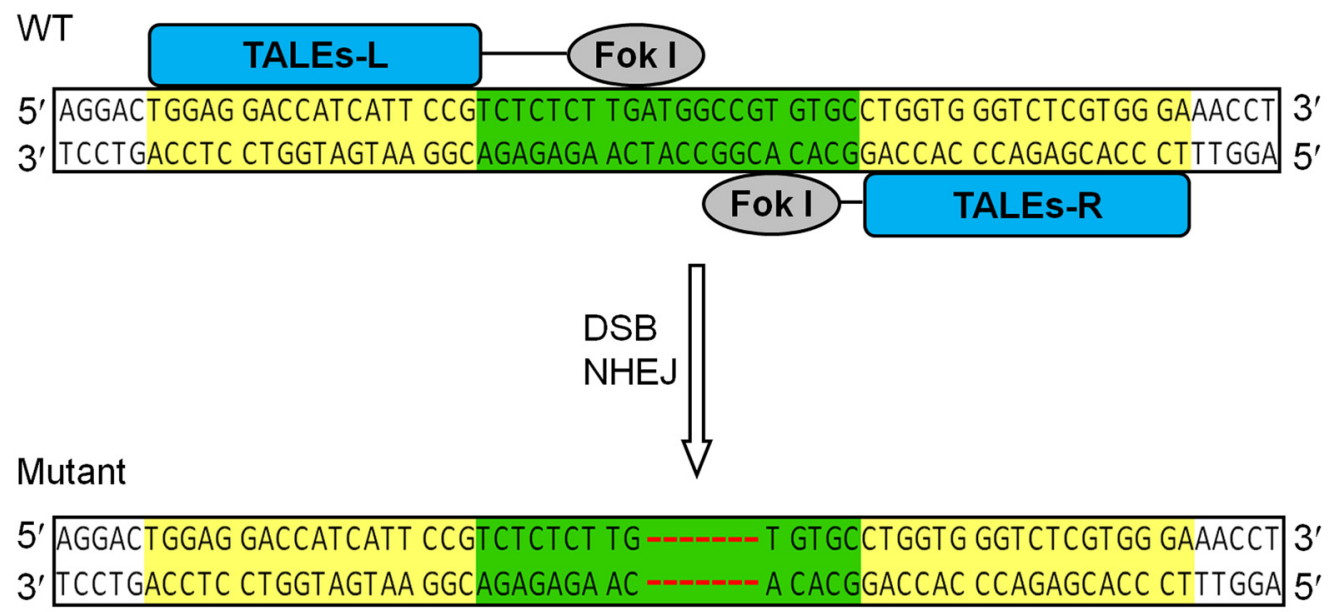

B
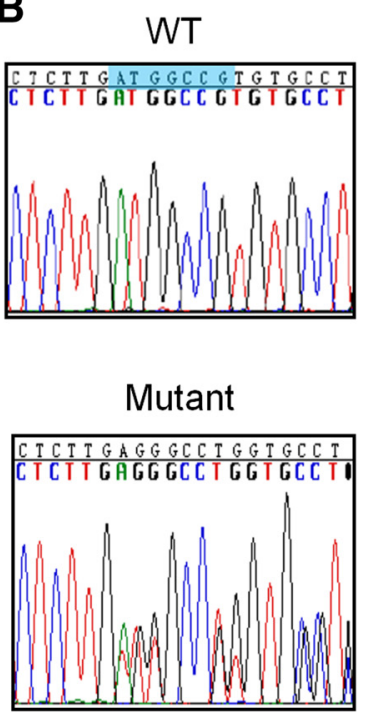

Figure 1. Generation of TALEN-mediated GPR151 mutant mice. A, A schematic shows the binding sites of TALENs (yellow) and space region (green) on Exon 1 of GPR151. Fokl, An endonuclease. $B$, DNA sequencing shows the deletion of seven bases (ATGGCCG) in the chimera mice (F0 generation).

Table 1. Primers sequences for real-time PCR

\begin{tabular}{|c|c|c|c|}
\hline Gene & Primers & Primer sequence, $5^{\prime}-3^{\prime}$ & Amplicon size, bp \\
\hline \multirow[t]{2}{*}{ GAPDH } & Forward & GCTTGAAGGTGTTGCCCTCAG & \multirow[t]{2}{*}{201} \\
\hline & Reverse & AGAAGCCAGCGTTCACCAGAC & \\
\hline \multirow[t]{2}{*}{ GPR151 } & Forward & ACACGAAGGCCAAGAGACAG & \multirow[t]{2}{*}{273} \\
\hline & Reverse & GCCAGCGTGAGCCCTATAAT & \\
\hline \multirow{2}{*}{ DNMT3b } & Forward & CTGTCCGAACCCGACATAGC & \multirow[t]{2}{*}{120} \\
\hline & Reverse & CCGGAAACTCCACAGGGTA & \\
\hline \multirow[t]{2}{*}{ KLF5 } & Forward & CCGGAGACGATCTGAAACACG & \multirow[t]{2}{*}{233} \\
\hline & Reverse & GTTGATGCTGTAAGGTATGCCT & \\
\hline \multirow[t]{2}{*}{ FGF14 } & Forward & TTCTCAGGGTGTCTAAGCTGC & \multirow[t]{2}{*}{141} \\
\hline & Reverse & GGGGATCAGTTGGGTTCTTGTT & \\
\hline \multirow[t]{2}{*}{ PRKACA } & Forward & AGATCGTCCTGACCTTTGAGT & \multirow[t]{2}{*}{119} \\
\hline & Reverse & GGCAAAACCGAAGTCTGTCAC & \\
\hline \multirow[t]{2}{*}{ CRK } & Forward & GGAGGTCGGTGAGCTGGTA & \multirow[t]{2}{*}{75} \\
\hline & Reverse & CGTTTGCCATTACACTCCCCT & \\
\hline \multirow[t]{2}{*}{ МАРЗК13 } & Forward & CCCGACCTCATCTCCACAG & \multirow[t]{2}{*}{113} \\
\hline & Reverse & TGGAAACAGGGATCATAGGGTT & \\
\hline \multirow[t]{2}{*}{ GRB2 } & Forward & ACAGCTAGGCAGATTTCCAGG & \multirow[t]{2}{*}{124} \\
\hline & Reverse & CAAGACAGCCCCAGTAGGT & \\
\hline
\end{tabular}

for $10 \mathrm{~min}$ to stop the reaction. As for the second step for reverse transcription (Invitrogen), the collections were performed at $50^{\circ} \mathrm{C}$ for $50 \mathrm{~min}$ and $70^{\circ} \mathrm{C}$ for $15 \mathrm{~min}$ to stop the reaction. The harvested cDNA fragments were then amplified using the constructed GPR151, NeuN, and GAPDH outer primers (Table 2) for $30-40$ cycles at $58^{\circ} \mathrm{C}$ for $10 \mathrm{~s}$ and at $72^{\circ} \mathrm{C}$ for $30 \mathrm{~s}$. The PCR productions were diluted for 1000 -fold to be further amplified using constructed inner primers (Table 2) for 30 cycles at $58^{\circ} \mathrm{C}$ for $10 \mathrm{~s}$ and $72^{\circ} \mathrm{C}$ for $30 \mathrm{~s}$. The final PCR products were visualized by GelRed (Biotium) staining in 3\% agarose gels.

Methylation-specific PCR. The genomic DNA was extracted through a QIAamp DNA Mini Kit (Qiagen) according to the manufacturer's protocol. Sodium bisulfite conversion of genomic DNA was performed using an EpiTect Bisulfite Kit (Qiagen). Bisulfite-converted genomic DNA was amplified with EpiTect Master Mix for methylation-specific PCR (MSP; Qiagen) with methylation-specific or unmethylation-specific primers (Table 3). The PCR products were analyzed by electrophoresis. The percentage of methylation of the GPR151 promoter from the spinal cord of SNL- or sham-operated animals was detected through densitometric analysis of MSP products (ratio of methylated products to unmethylated products).
Table 2. Primers sequences for single-cell PCR

\begin{tabular}{|c|c|c|c|}
\hline Gene & Primers & Primer sequence, $5^{\prime}-3^{\prime}$ & Amplicon size, bp \\
\hline \multirow[t]{2}{*}{ GPR151-0UT } & Forward & GGTTTGCCGACACCAATTCC & 314 \\
\hline & Reverse & GAACCAGCCGAGATCCCAAA & \\
\hline \multirow[t]{2}{*}{ GPR151-IN } & Forward & GTTTGCTCGCCTCCACTTTG & 119 \\
\hline & Reverse & CACACAGGTTTCCCACGAGA & \\
\hline \multirow[t]{2}{*}{ NeuN-OUT } & Forward & AGACAGACAACCAGCAACTC & 357 \\
\hline & Reverse & CTGTTCCTACCACAGGGTTTAG & \\
\hline \multirow[t]{2}{*}{ NeuN-IN } & Forward & ACGATCGTAGAGGGACGGAA & 86 \\
\hline & Reverse & TTGGCATATGGGTTCCCAGG & \\
\hline \multirow[t]{2}{*}{ GAPDH-OUT } & Forward & AGCCTCGTCCCGTAGACAAAA & 367 \\
\hline & Reverse & TTTTGGCTCCACCCCTTCA & \\
\hline \multirow[t]{2}{*}{ GAPDH-IN } & Forward & TGAAGGTCGGTGTGAACGAATT & 313 \\
\hline & Reverse & GCTTTCTCCATGGTGGTGAAGA & \\
\hline
\end{tabular}

Table 3. Primers sequences for BSP, MSP, and ChIP experiments

\begin{tabular}{llll}
\hline Gene & Primers & Primer sequence, $5^{\prime}$-3' $^{\prime}$ & Amplicon size, bp \\
\hline GPR151MSP, unmethylated & Forward & ATATGAATGAGTCGTTTGTTC & 100 \\
& Reverse & ACACAACCATCAAAAAAAACG & \\
GPR151MSP, methylated & Forward & GTAATATGAATGAGTTGTTTGTT & 100 \\
& Reverse & ACACAACCATCAAAAAAAACAA & \\
GPR151BSP & Forward & GTAATGTTGAGAGTTGGGTTTG & 250 \\
& Reverse & CCAAACTTAAATTCAAAATCAAA & \\
GPR151 ChIP & Forward & GTTGGTCGCTCCACTTTG & 119 \\
& Reverse & CACACAGGTTCCCACGAGA & \\
\hline
\end{tabular}

Bisulfite sequencing PCR. The genomic DNA extraction and bisulfite treatment were performed as described in the MSP method. PCR was performed to amplify the CpG island fragment of the GPR151 promoter from bisulfite-converted genomic DNA using the primers shown in Table 3. Then the PCR products were purified with the QIAquick Gel Extraction Kit (Qiagen). The eluted DNA fragments were ligated into pGEM-T Easy Vector (Promega) for sequencing. Ten colonies for each mouse were randomly chosen for sequencing.

GPR151 promoter activity analysis. The GPR151 promoter reporter cloned into the $\mathrm{pCpG}$-free basic reporter vector (InvivoGen) was either methylated by incubation with S-adenosyl methionine or unmethylated in the presence or absence of CpG methylase M.SssI (ThermoFisher Scientific). The methylated or unmethylated pCpG-free-GPR151-Lucia luciferase reporter plasmid was transfected into HEK293 cells (CLS, catalog \#300192/p777_HEK293; RRID:CVCL_0045) by Lipofectamine 
3000 (Invitrogen). Meanwhile, the cells were cotransfected with KLF5 overexpression plasmid. The activity of secreted coelenterazine luciferase in the medium was detected $48 \mathrm{~h}$ later using the Dual-Luciferase Assay System (Promega) following the instructions. Twenty microliters of the medium samples were subjected to luciferase assay (Synergy 2 MultiMode Reader, BioTEL). The predicted five mutant KLF5 binding sites (BS1-BS5) in GPR151 gene promoter of luciferase reporter vectors were purchased from Sangon Biotech and were cotransfected with KLF5 overexpression plasmid in HEK-293 cells. The activity of luciferase was measured $48 \mathrm{~h}$ later using the Dual-Luciferase Assay System (Promega).

Chromatin immunoprecipitation PCR. Chromatin immunoprecipitation (ChIP) assay was performed using the Simple ChIP Enzymatic Chromatin IP Kit (Magnetic Beads, Cell Signaling Technology) according to the instructions. The ipsilateral dorsal horn of SNL- or shamoperated mice was collected in $1 \%$ formaldehyde immediately to crosslink the proteins to the DNA. After glycine treatment and PBS washing, the tissues were homogenized and lysed. The chromatin was then collected and fragmented using enzymatic digestion. The disposed chromatin was subjected to immunoprecipitation with normal IgG antibody (rabbit, 1:500; Cell Signaling Technology, catalog \#2729S; RRID: AB_1031062) as negative control (NC), histone H3 antibody (rabbit, 1:50; Cell Signaling Technology, catalog \#4620S; RRID:AB_1904005) as positive control, DNMT3b antibody (mouse, 1:200; Abcam, catalog \#ab13604; RRID:AB_300494), and KLF5 antibody (rabbit, 1:300; Millipore, catalog \#07-1580; RRID:AB_1977308). The mixture was captured by protein-G magnetic beads. After immunoprecipitation, the proteinDNA crosslinks were reversed, and the DNA was purified. The enrichment of the GPR151 promoter sequences was measured through quantitative ChIP-PCR (qChIP-PCR) using the DNMT3b or KLF5 sitespecific primer pairs in the GPR151 promoter (Table 3). ChIP-PCR products were visualized by GelRed (Biotium) staining in 3\% agarose gels. As for qChIP-PCR, DNA samples and standards were analyzed using FastStart Essential DNA Green Master for SYBR Green I based realtime PCR (Roche Diagnostics) through the Light Cycler 96 Real-time PCR System (Roche Diagnostics).

In situ hybridization. The template fragments of GPR151 were amplified by PCR using primers (forward: $5^{\prime}$-CGG GAT CCC GCA CGC AGG TGT GGA AAT GTG-3' and reverse: 5' -ACG AGC TCG CTG TCA TCA GGA GAC CCA C- $3^{\prime}$ ) and subcloned into pSPT18. Digoxigenin (DIG)labeled RNA antisense and sense probes for the GPR151 gene were synthesized using the DIG RNA Labeling Kit (SP6/T7, Roche). Cellular localization of GPR151 mRNA was performed using in situ hybridization assay kit (Boster Biological Technology). Briefly, the spinal cord sections and DRG sections $(14 \mu \mathrm{m})$ were treated with $30 \% \mathrm{H}_{2} \mathrm{O}_{2}$ and methanol (1:50) for $30 \mathrm{~min}$ at room temperature. After being washed with DEPCtreated ultrapure water, the sections were prehybridized at $42^{\circ} \mathrm{C}$ for $4 \mathrm{~h}$ at room temperature and hybridized with the DIG-labeled probe $(1 \mu \mathrm{g} / \mathrm{ml})$ in hybridization buffer at $42^{\circ} \mathrm{C}$ overnight. After being washed by sodium chloride-sodium citrate buffer, sections were then incubated in blocking solution at $37^{\circ} \mathrm{C}$ for $30 \mathrm{~min}$ and in mouse anti-DIG-biotin for $60 \mathrm{~min}$ at room temperature, washed with $\mathrm{PBS}(0.01 \mathrm{M}, \mathrm{pH} 7.4)$, and then incubated in streptavidin-biotin complex-Cy3 reagent (Boster Biological Technology) for $30 \mathrm{~min}$ at $37^{\circ} \mathrm{C}$.

To further identify the cell types expressing GPR151 and the colocalization of GPR151 with KLF5 in the spinal cord, the sections under in situ hybridization were incubated overnight using primary antibodies against NeuN (mouse, 1:1000; Millipore, catalog \#MAB377; RRID: AB_2298772), GFAP (mouse, 1:6000; Millipore, catalog \#MAB360; RRID:AB_2275415), IBA-1 (rabbit, 1:3000; Wako, catalog \#019-19741; RRID:AB_839504), and KLF5 (rabbit, 1:300; Millipore, catalog \#071580; RRID:AB_1977308) and then further incubated with AlexaFluor 488 goat anti-mouse IgG $(\mathrm{H}+\mathrm{L})$ or AlexaFluor 488 goat anti-rabbit IgG $(\mathrm{H}+\mathrm{L}$; Jackson ImmunoResearch) for $2 \mathrm{~h}$ at room temperature. The signals were detected with Leica SP8 confocal microscope.

Immunohistochemistry. Animals were anesthetized with isoflurane and perfused through the ascending aorta with $0.9 \% \mathrm{NaCl}$ followed by $4 \%$ paraformaldehyde in $0.1 \mathrm{M} \mathrm{PB}$. After perfusion, the L4-L5 spinal cord segments were removed and postfixed in the same fixative $4-6 \mathrm{~h}$ at $4^{\circ} \mathrm{C}$. Spinal cord sections ( $30 \mu \mathrm{m}$, free-floating) were cut in a cryostat and processed for immunofluorescence. The sections were first blocked with $4 \%$ goat serum or donkey serum for $2 \mathrm{~h}$ at room temperature and then incubated overnight at $4^{\circ} \mathrm{C}$ with the following primary antibodies: glial fibrillary acidic protein (GFAP; mouse, 1:6000; Millipore, catalog \#MAB360; RRID:AB_2275415), NeuN (mouse, 1:1000; Millipore, catalog \#MAB377; RRID:AB_2298772), CD11b (mouse, 1:50; Serotec, catalog \#MCA-257GA; RRID:AB_566455), IBA-1 (rabbit, 1:3000; Wako, catalog \#019-19741; RRID:AB_839504), KLF5 (rabbit, 1:300; Millipore, catalog \#07-1580; RRID:AB_1977308), calcitonin gene-related peptide antibody (CGRP; mouse, 1:500; Sigma-Aldrich, catalog \#C7113; RRID: AB_259000), PKC $\gamma$ (mouse, 1:500; Santa Cruz Biotechnology, catalog \#sc-166451; RRID:AB_2168997), and isolectin $B_{4}$ (IB4; 1:50; SigmaAldrich, catalog \#L2140; RRID:AB_2313663). The sections were then incubated $2 \mathrm{~h}$ at room temperature with Cy3- or AlexaFluor 488conjugated secondary antibodies (1:1000; Jackson ImmunoResearch). For double-immunofluorescence, sections were incubated with a mixture of mouse and rabbit primary antibodies followed by a mixture of Cy3- or AlexaFluor 488-conjugated secondary antibodies. The stained sections were examined with a Leica SP8 Gated STED confocal microscope (Leica Microsystems).

Western blot. Animals were perfused with $0.9 \% \mathrm{NaCl}$. Spinal cord tissues were homogenized in a RIPA lysis buffer containing protease and phosphatase inhibitors (Roche). Protein samples (30 $\mu \mathrm{g})$ were separated on an SDS-PAGE gel and transferred to PVDF (Millipore) blots. The blots were blocked with 5\% skim milk in TBST and incubated with antibody against DNMT3B (goat, 1:300; Santa Cruz Biotechnology, catalog \#sc-10236; RRID:AB_2094128), pERK (rabbit, 1:1000; Cell Signaling Technology, catalog \#9101; RRID:AB_331646), ERK (catalog \#9102; RRID:AB_330744), pJNK (catalog \#9251; RRID:AB_331659), JNK (catalog \#9252; RRID:AB_2250373), pp38 (catalog \#9211; RRID: AB_331641), and p38 (catalog \#9212; RRID:AB_330713). The blots were further incubated with GAPDH antibody (mouse, 1:20,000; Millipore, catalog \#MAB374; RRID:AB_2107445) for the control group. Then these bolts were incubated with IRDye 800CW Goat Anti-Mouse IgG (H + L; LI-COR Biosciences, catalog \#P/N 925-32210; RRID:AB_2687825) or IRDye 800CW Goat Anti-Rabbit IgG (H + L; LI-COR Biosciences, catalog \#925-32211; RRID:AB_2651127) for $2 \mathrm{~h}$ at room temperature and displayed through Odyssey CLx Imaging System (LI-COR). Specific bands were evaluated by predicted molecular size, and the intensity of selected bands was analyzed by ImageJ software (National Institutes of Health; RRID:SCR_003070).

Microarray. Total RNA was isolated from the L5 spinal cord at $10 \mathrm{~d}$ after SNL using the TRIzol reagent (Invitrogen). There were two replicates for RNA samples from WT or GPR151 ${ }^{-1-}$ mice. Gene expression profiles of the spinal cord were assessed with Agilent SurePrint G3 Mouse GE $8 \times 60$ K Microarray Kit (G4852A) by CapitalBio. Gene expression data of sham-operated mice is from our previously reported data (Jiang et al., 2016).

Lentiviral vectors production and intraspinal injection. The shRNAs targeting murine GPR151 (GenBank accession: NM_181543.1. 5' -CCA TCA TTC CGT CTC TCT T- $\left.3^{\prime}\right)$ and a NC shRNA (5' - TTC TCC GAA CGT GTC ACG T-3') were designed and inserted into lentiviral vector pGV248 which regulates the expression of shRNAs by the U6 promoter (LV-GPR151 shRNA or LV-NC). The coding sequence of DNMT3b (GenBank accession: NM_001122997.2) of mice was synthesized by Sangon Biotech and cloned into pLV-Ubi-MCS-3FLAG to generate DNMT3b-expressing lentiviral plasmid, which mediated transcription of $D N M T 3 b$ by ubiquitin promoter. Then the DNMT3b-expressing plasmid and EGFP-expressing plasmid (Control) were packaged into lentivirus. For the intraspinal injection, animals were anesthetized with isoflurane and performed with hemilaminectomy at the L1-L2 vertebral segments. After exposure of the spinal cord, each animal received two injections $(0.5 \mu \mathrm{l}, 0.8 \mathrm{~mm}$ apart and $0.5 \mathrm{~mm}$ deep $)$ of the lentivirus $(1 \times$ $10^{5} \mathrm{TU}$ ) along the L4-L5 dorsal root entry zone using a glass micropipette (diameter $60 \mu \mathrm{m}$ ). The tip of glass micropipette reached to the depth of lamina II-IV of the spinal cord. The dorsal muscle and skin were sutured. The intraspinal injection was performed unilaterally on the left side (Jiang et al., 2016). 
A

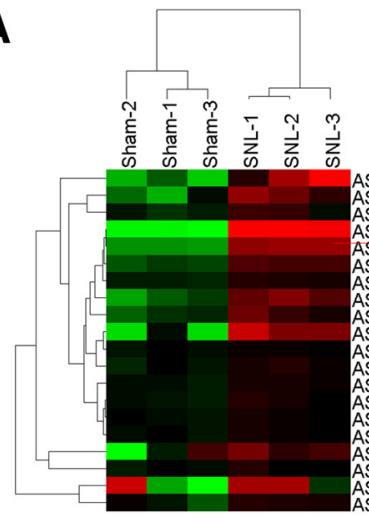

B

\begin{tabular}{ccc}
\hline $\begin{array}{c}\text { Fold } \\
\text { of change }\end{array}$ & $\begin{array}{c}\text { Gene } \\
\text { symbol }\end{array}$ & Probe ID \\
\hline $\mathbf{2 6 . 2 9 4}$ & GPR151 & ASMM9PARTA044047 \\
$\mathbf{5 . 2 1 8}$ & GPR150 & ASMM9PARTA042608 \\
$\mathbf{3 . 0 0 6}$ & GPR84 & ASMM9PARTA037972 \\
$\mathbf{2 . 3 5 8}$ & GPR160 & ASMM9PARTA024012 \\
$\mathbf{1 . 9 4 7}$ & GPR124 & ASMM9PARTA038136 \\
$\mathbf{1 . 7 7 4}$ & GPR152 & ASMM9PARTA044450 \\
$\mathbf{1 . 7 1 3}$ & GPR174 & ASMM9PARTA026817 \\
$\mathbf{1 . 5 3 0}$ & GPR160 & ASMM9PARTA036138 \\
\hline
\end{tabular}
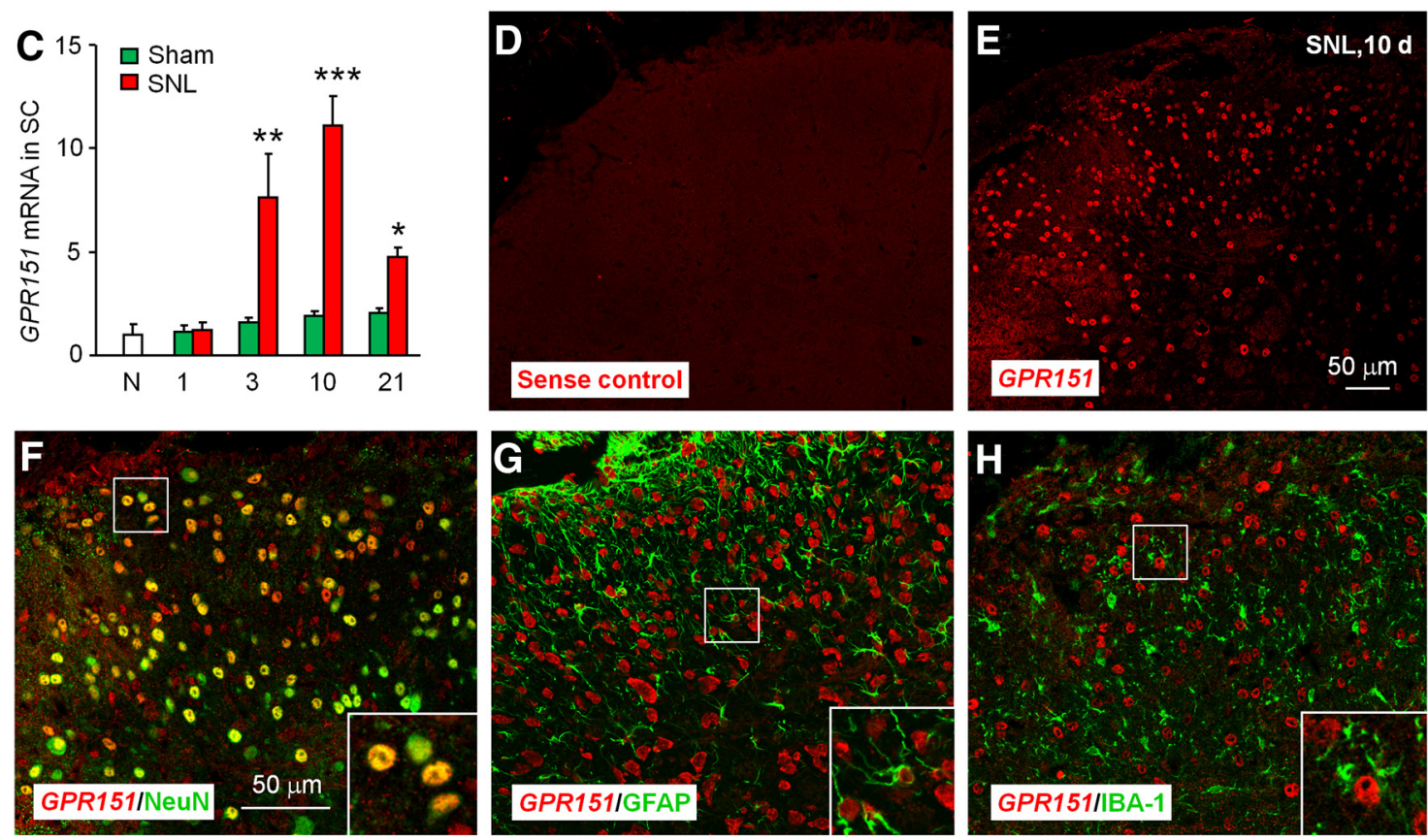

I
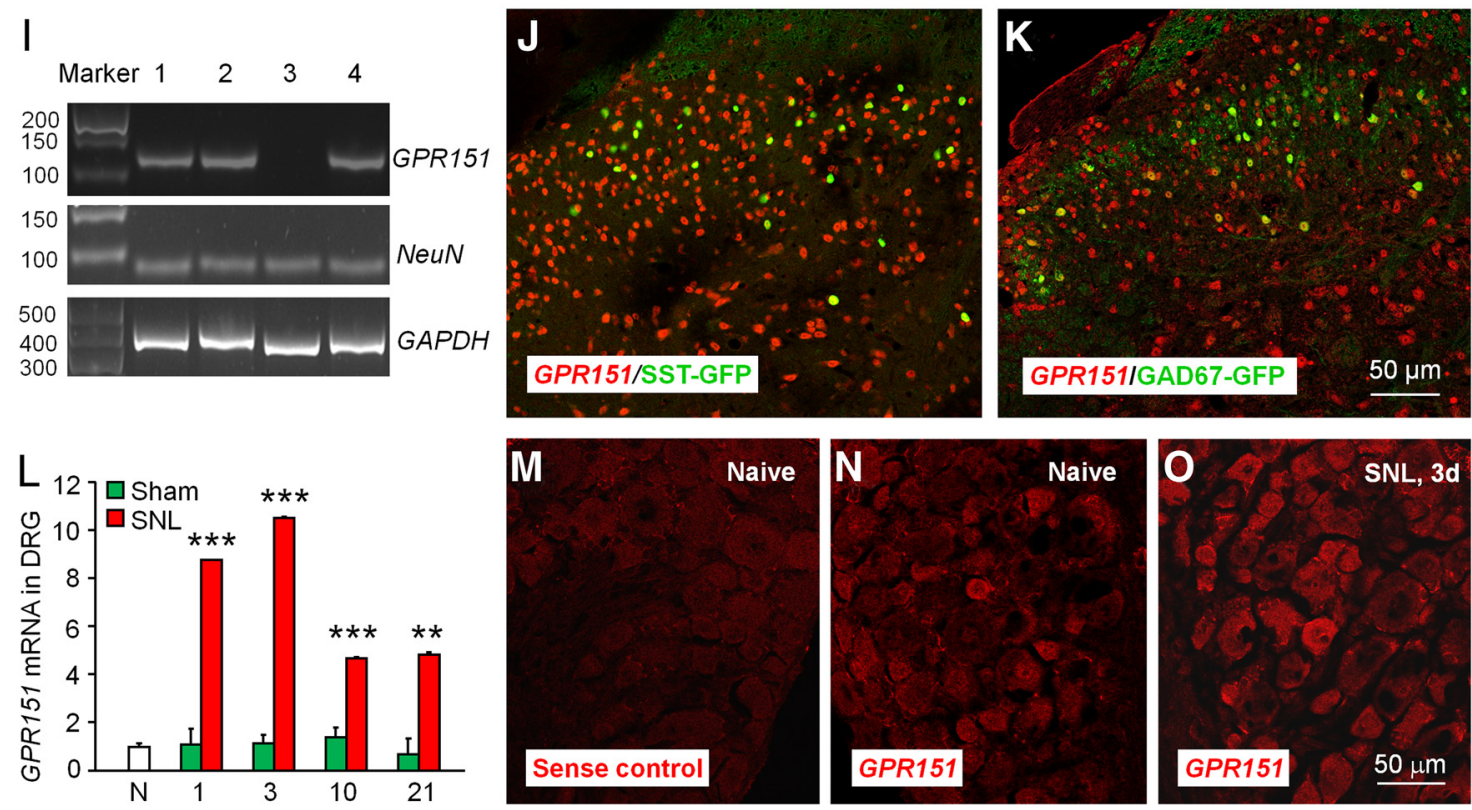

Figure 2. GPR151 expression is increased in the spinal cord after SNL. $A$, Gene chip shows the upregulation of several GPCRs genes after SNL. $B$, There are eight GPCRs whose expression was increased $>1.5$-fold after SNL.C, The time course of GPR151 mRNA expression in the ipsilateral dorsal horn in naive, sham-, and SNL-operated mice. ${ }^{*} p<0.05,{ }^{* * *} p<0.01$, ${ }^{* * *} p<0.001$, versus sham. Student's t test. $n=6$ mice/group. SC, Spinal cord. N, naive. D, E, In situ hybridization of GPR151 mRNA shows that no signal was found in spinal sections incubated with GPR151 sense probe (D), and positive signals were shown in spinal sections incubated with GPR151 antisense probe (E). $\boldsymbol{F}-\boldsymbol{H}$, In situ hybridization of GPR151 mRNA and immunofluorescence (Figure legend continues.) 
Behavioral analysis. Animals were habituated to the testing environment daily for $2 \mathrm{~d}$ before baseline testing. All the testings were done by individuals blinded to the treatment or genotypes of the mice. In the tail immersion test, the temperature of the water was set at 48,50 , and $52^{\circ} \mathrm{C}$, and the tail-flick latency was recorded. To test the hyperalgesia, the animals were put on a glass plate within a plastic box and allowed $30 \mathrm{~min}$ for habituation. Heat sensitivity was tested by radiant heat using Hargreaves apparatus (IITC, model 390 Analgesia Meter, Life Science), which was expressed as paw withdrawal latency. The latency baseline was adjusted to $10-14 \mathrm{~s}$ with a maximum of $20 \mathrm{~s}$ as cutoff to prevent potential injury (Hargreaves et al., 1988). For mechanical allodynia, animals were put on an elevated metal mesh floor and allowed $30 \mathrm{~min}$ for habituation before an examination. The plantar surface of the hindpaw was stimulated with a series of von Frey hairs with logarithmically incrementing stiffness (0.02-2.56 g, Stoelting) presented perpendicular to the plantar surface (2-3 s for each hair). The $50 \%$ paw withdrawal threshold was determined using Dixon's up-down method (Dixon, 1980). For the Rotarod test, the speed was set at $10 \mathrm{rpm}$ for $60 \mathrm{~s}$ and subsequently accelerated to $80 \mathrm{rpm}$ within $5 \mathrm{~min}$. The time for mice to fall after the beginning of the acceleration was recorded (Abbadie et al., 2003).

Experimental design and statistical analysis. All sample sizes and experimental design were based on previously published data from our lab and similar experiments in the field. All quantitative analysis were performed double-blinded. All data were expressed as mean \pm SEM. The $n$ number stands for the biological repeat. Each $n$ number is indicated in the figures or the figure legends. All statistical analyses were performed using GraphPad Prism 5. Student's two-tailed $t$ test was used for two group comparisons, and one-way ANOVA or two-way repeated-measures (RM) ANOVA was used for multigroup comparisons, followed by post hoc Bonferroni tests. The criterion for statistical significance was $p<0.05$. Details for statistical tests used are provided within figure legends or in Results.

\section{Results \\ GPR151 expression is upregulated in spinal neurons} after SNL

To search for novel GPCR genes and regulatory networks that are critical for the maintenance of neuropathic pain, we performed a genome-wide gene expression profiling analysis of the ipsilateral spinal cord dorsal horn $10 \mathrm{~d}$ after SNL (Jiang et al., 2015). Among all detectable oGPCR genes, eight of them (GPR151, GPR150, GPR84, GPR160, GPR124, GPR152, GPR174, and GPR160) were upregulated by $>1.5$-fold (Fig. $2 A, B$ ). Strikingly, GPR151 was the most dramatically increased gene with a 26 -fold increase $(p=$ 0.000, Student's $t$ test; Fig. 2B).

We then checked the time course of GPR151 expression in the ipsilateral dorsal horn after SNL or sham-operation by qPCR. GPR151 mRNA was significantly increased at Day 3, peaked at Day 10, and maintained at Day 21 in SNL mice $\left(F_{(4,23)}=12.152\right.$, $p=0.000$, one-way ANOVA; Fig. $2 C$ ). The mRNA level did not significantly differ between naive and sham-operated mice at all the time points we checked $\left(F_{(4,24)}=1.850, p=0.159\right.$, one-way ANOVA; Fig. 2C).

To define the cellular localization of GPR151 in the spinal cord, we performed in situ hybridization using antisense probes for GPR151 on spinal sections of SNL $10 \mathrm{~d}$. The GPR151-positive signal was not shown in sections incubated with GPR151 sense

\section{$\leftarrow$}

(Figure legend continued.) staining with $\operatorname{NeuN}(\boldsymbol{F}), \operatorname{GFAP}(\boldsymbol{G})$, and IBA-1 (H). I, Single-cell PCR shows the coexpression of GPR151 with neuronal marker NeuN. J, $\boldsymbol{K}$, In situ hybridization of GPR151 mRNA on the spinal cord from SST-GFP $(\boldsymbol{J})$ and GAD67-GFP $(\boldsymbol{K})$ mice $10 \mathrm{~d}$ after SNL. $L$, The time course of GPR151 mRNA expression in L5 DRG. ${ }^{* *} p<0.01$, ${ }^{* * *} p<0.001$, versus sham. Student's $t$ test. $n=4-6$ mice/group. $N$, naive. $\boldsymbol{M}-\mathbf{0}$, The images of in situ hybridization of GPR151 mRNA in DRG sections incubated with GPR151 sense probe $(\boldsymbol{M})$ or GPR151 antisense probe from naive $(\boldsymbol{N})$ or SNL $(\mathbf{0})$ animals. probe (Fig. 2D) but shown in sections with antisense probe (Fig. $2 E)$. In situ hybridization combined with immunostaining showed that GPR151 was primarily colocalized with neuronal marker NeuN (Fig. $2 F$ ), rarely with astrocytic marker GFAP (Fig. $2 G$ ), none with microglial marker IBA-1 (Fig. $2 H$ ). In lamina I-II and III-IV, $72.4 \pm 4 \%$ and $73.2 \pm 3 \%$ of NeuN-positive cells express GPR151, respectively. Single-cell RT-PCR analysis revealed coexpression of GPR151 with NeuN in 3 of 4 neurons in lamina II (Fig. 2I). These data suggest the predominant expression of GPR151 in spinal neurons.

We further characterized the type of $G P R 151^{+}$neurons. As somatostatin (SST) and GAD67 are respectively expressed in excitatory and inhibitory neurons (Zeilhofer et al., 2012; Duan et al., 2014), we performed GPR151 in situ hybridization on SST$\mathrm{GFP}^{+}$or GAD67-GFP ${ }^{+}$mice. It showed that GPR151 is expressed in $\mathrm{SST}$-GFP ${ }^{+}$neurons and $\mathrm{GAD}^{+} 7-\mathrm{GFP}^{+}$neurons (Fig. $2 J, K)$, suggesting that GPR151 is extensively expressed in dorsal horn neurons.

GPR151 was reported to be highly increased in the DRG after CCI or burn injury (Reinhold et al., 2015; Yin et al., 2016), we then checked GPR151 expression in the DRG after SNL. As shown in Figure 2L, GPR151 was dramatically increased at Days $1,3,10$, and 21 after SNL $\left(F_{(4,20)}=37.29, p=0.000\right.$, one-way ANOVA). In situ hybridization showed that GPR151 is expressed in neuron-like cells in the DRG of naive mice and increased after SNL (Fig. 2M-O).

\section{Mutation or inhibition of GPR151 persistently attenuates SNL-induced pain hypersensitivity}

To determine the role of GPR151 in pain sensation, GPR151 mutant mice $\left(G P R 151^{-1-}\right)$ were generated (Figs. 1, Fig. 3A,B). GPR $151^{-1-}$ mice show normal distribution patterns of the neuronal marker NeuN, astrocyte marker GFAP, microglia marker IBA-1 (Fig. 3C), and normal innervations of the primary afferents, labeled with CGRP and IB4, and normal neurochemical marker PKC $\gamma$ in the spinal cord dorsal horn (Fig. 3D).

We further tested pain behaviors and motor function in WT and GPR $151^{-1-}$ mice (Fig. 4A). Acute thermal sensitivity tested by hot water-immersion and radiant heat, acute mechanical sensitivity tested by von Frey, were indistinguishable in WT and GPR $151^{-1-}$ mice (tail-flick test: $F_{(1,45)}=0.06, p=0.8126$, twoway ANOVA; radiant heat test: $p=0.924$, Student's $t$ test; Von Frey test: $p=0.6672$, Student's $t$ test). The rotarod test revealed a similar falling latency in WT and GPR151 $1^{-1-}$ mice $(p=0.6672$, Student's $t$ test). These data indicate that GPR151 mutation did not cause deficits in basal pain sensation and motor function.

Next, we tested pain behaviors after SNL. Consistent with previous reports (Jiang et al., 2016), SNL induced persistent mechanical allodynia (Fig. 4B) and heat hyperalgesia (Fig. 4C) in WT mice. However, SNL-induced mechanical allodynia was markedly reduced in GPR $151^{-1-}$ mice from 3 to $42 \mathrm{~d}\left(F_{(1,88)}=\right.$ $117.33, p=0.000$, two-way RM ANOVA; Fig. $4 B$ ). In addition, heat hyperalgesia was not developed in GPR $151^{-1-}$ mice in $42 \mathrm{~d}$ $\left(F_{(1,88)}=248.98, p=0.000\right.$, two-way RM ANOVA; Fig. $\left.4 C\right)$.

To further investigate the role of spinal GPR151 in the maintenance of neuropathic pain, we intraspinally injected GPR151 shRNA lentivirus (LV-GPR151 shRNA) and control lentivirus (LV-NC) $5 \mathrm{~d}$ after SNL in WT mice. An in vitro study in HEK293 cells showed that the LV-GPR151 shRNA reduced GPR151 expression by $94.9 \pm 0.5 \%$ compared with LV-NC $(p=0.000$, Student's $t$ test, $n=4$ /group). Intraspinal injection of LVGPR151 shRNA attenuated SNL-induced mechanical allodynia from 7 to $63 \mathrm{~d}$ after SNL, and the second injection also effectively 
A

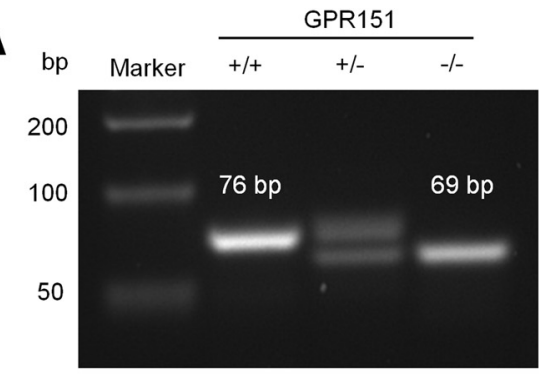

B

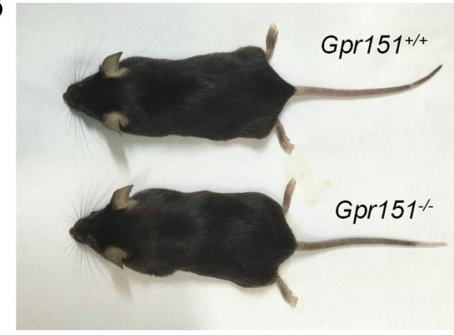

C
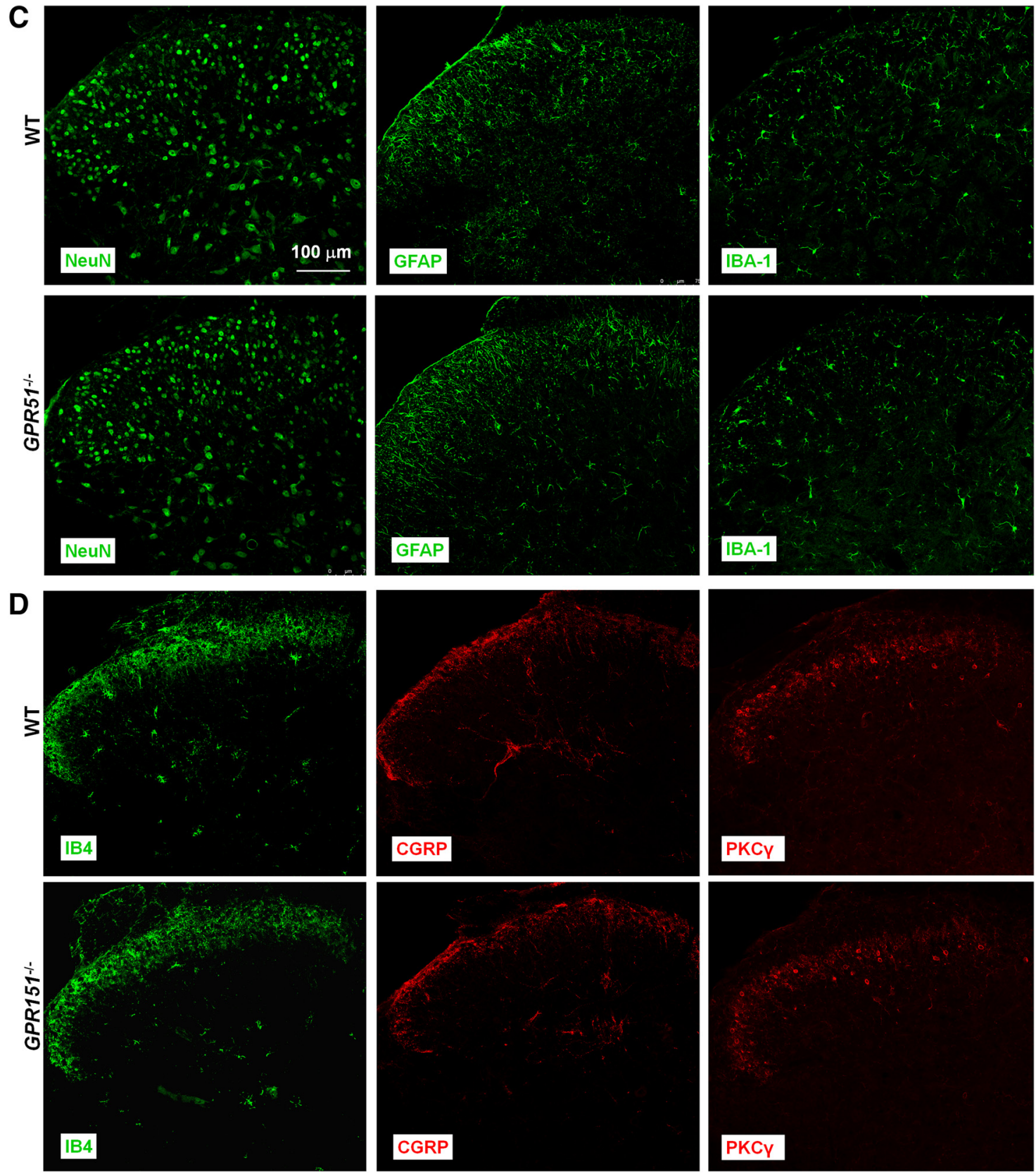

Figure 3. GPR151 K0 mice are normal in the expression of cellular markers and neurochemical markers. $A$, PCR-based genotyping of WT and GPR151 $1^{-1-}$ mice. ${ }^{+/+}$, ${ }^{+/-}$, and ${ }^{-1-}$ indicate

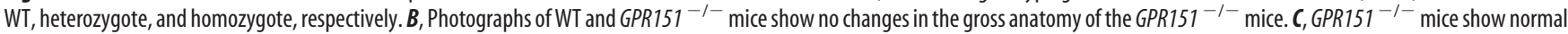
distribution patterns in the spinal dorsal horn of the neurochemical marker NeuN, astrocytic marker GFAP, and microglial marker Iba-1.D, The expression of IB4 ${ }^{+}$non-peptidergic primary afferents, $\mathrm{CGRP}^{+}$peptidergic primary afferents, and neurochemical marker PKC $\gamma$ is normal in GPR151 ${ }^{-1-}$ mice.

attenuated mechanical allodynia $\left(F_{(1,162)}=150.28, p=0.000\right.$, two-way RM ANOVA; Fig. 4D). LV-GPR151 shRNA treatment reversed SNL-induced heat hyperalgesia $\left(F_{(1,81)}=228.62, p=\right.$ 0.000, two-way RM ANOVA; Fig. 4E). qPCR data showed that spinal injection of LV-GPR151 shRNA reduced GPR151 mRNA expression in lumbar segments by $42.8 \pm 8.9 \%$ at SNL Day 21, $40.0 \pm 8.2 \%$ at Day 63, and $15.9 \pm 5.9 \%$ at SNL Day 77 compared with LV-NC (Day 21: $p=0.032$, Student's $t$ test, $n=6$ mice/ 
A

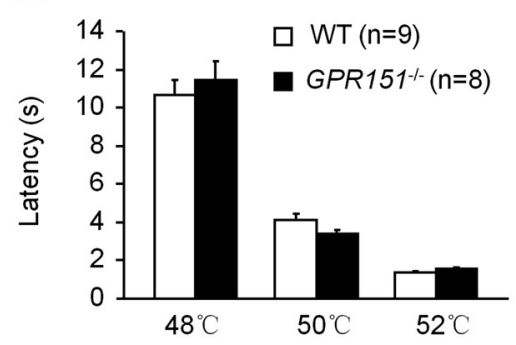

Hargreaves

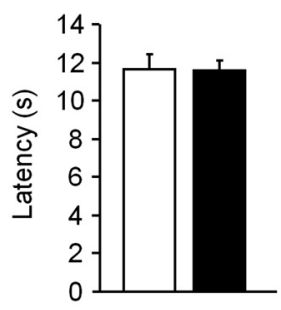

Von Frey

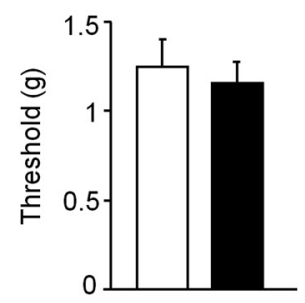

Rotarod

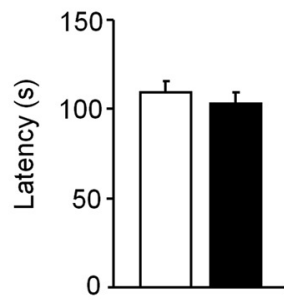

B

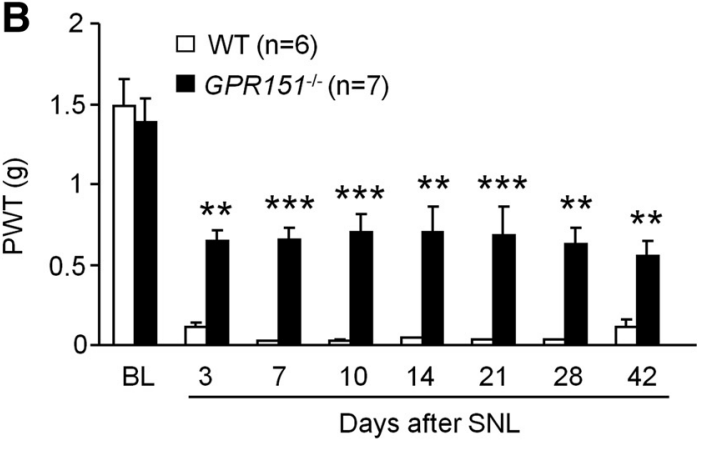

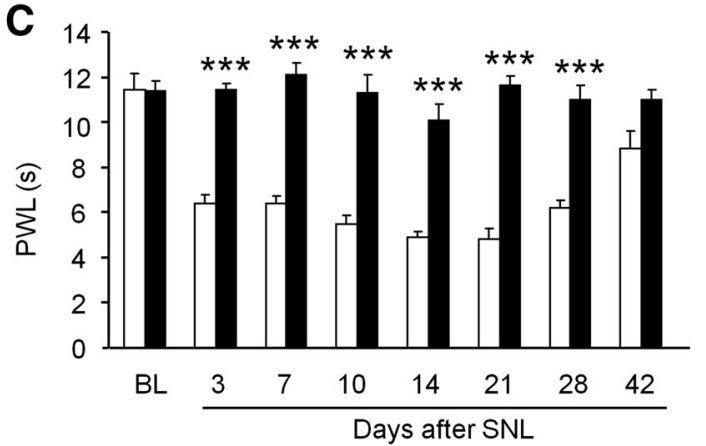

E

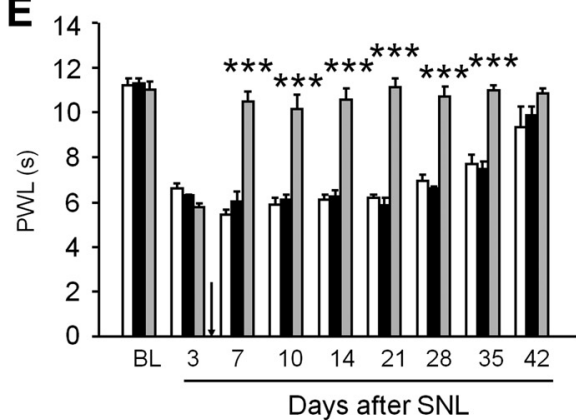

Figure 4. Mutation or inhibition of GPR151 alleviates SNL-induced neuropathic pain. $\boldsymbol{A}$, Acute pain threshold measured by tail immersion, Hargreaves test, von Frey test and motor function assessed by the rotarod test were comparable in WT and GPR151 ${ }^{-/-}$mice. $n=8-9$ mice/group. Student's $t$ test. $\boldsymbol{B}, \boldsymbol{C}$, SNL-induced mechanical allodynia $(\boldsymbol{B})$ and heat hyperalgesia $(\boldsymbol{C})$ were markedly alleviated in GPR151 ${ }^{-1-}$ mice compared with WT mice. $n=6-7$ mice/group. ${ }^{* *} p<0.01,{ }^{* * *} p<0.001$, versus WT. Two-way RM ANOVA followed by Bonferroni's tests. $\boldsymbol{D}, \boldsymbol{E}$, Intraspinal infusion of LV-GPR151 shRNA in the spinal cord alleviated SNL-induced mechanical allodynia $7 \mathrm{~d}$ after SNL (D) and blocked heat hyperalgesia $(\boldsymbol{E}) .{ }^{*} p<0.05,{ }^{* *} p<0.01,{ }^{* * *} p<0.001$, versus $\mathrm{LV}$-NC. Two-way RM ANOVA followed by Bonferroni's tests. $n=5-6$ mice/group.

group; Day 63: $p=0.008$, Student's $t$ test, $n=5$ mice/group; Day $77: p=0.084$, Student's $t$ test, $n=5$ mice/group), confirming the knockdown effect of LV-GPR151 shRNA at Days 21 and 63. Collectively, the behavioral results obtained by different strategies suggest that GPR151 plays a pivotal role in the maintenance of neuropathic pain.

\section{Demethylation of the CpG sites of GPR151 gene promoter after SNL}

DNA methylation is an essential epigenetic mechanism in controlling gene expression (Jaenisch and Bird, 2003). To determine how GRP151 expression is regulated, we examined the methylation status of GPR151 promoter region by MSP and bisulfite sequencing PCR (BSP) assays. The genomic structure of GPR151 gene contains one $\mathrm{CpG}$ dinucleotide region with $10 \mathrm{CpG}$ sites around the transcriptional starting site (Fig. 5A). The MSP assay showed that the methylation of the GPR151 promoter in the spinal cord dorsal horn of SNL mice was lower than that in shamoperated mice ( $p=0.020$, Student's $t$ test; Fig. $5 B$ ). To further confirm the methylation status of the $10 \mathrm{CpG}$ sites within the
GPR151 promoter, DNA sequencing was performed on PCR products of the $250 \mathrm{bp}$ fragment obtained after the treatment of genomic DNA samples with sodium bisulfite. As shown in Figure $5 C$, all samples were successfully sequenced. Consistent with the MSP assay, DNA methylation in $\mathrm{CpG}$ dinucleotide regions of GPR151 gene was decreased in SNL mice compared with shamoperated mice $\left(F_{(1,40)}=24.82, p=0.000\right.$, two-way ANOVA; Fig. $5 C, D)$.

The effect of DNA methylation on GPR151 promoter activity was further analyzed in a cell culture system using a coelenterazine-using luciferase assay. The luciferase activity was not different between transfection with methylated- and unmethylated-pCpG-free basic reporter vector in HEK293 cells ( $p>0.05$, two-way ANOVA followed by Bonferroni posttests; Fig. 5E). However, the activity was increased when the cells were transfected with unmethylated pCpG-free-GPR151-promoterLucia vector compared with that transfected with methylated one $(p<0.001$, two-way ANOVA followed by Bonferroni post-tests; Fig. $5 E$ ), indicating that the promoter activity of mouse GPR151 gene is increased by DNA demethylation. 


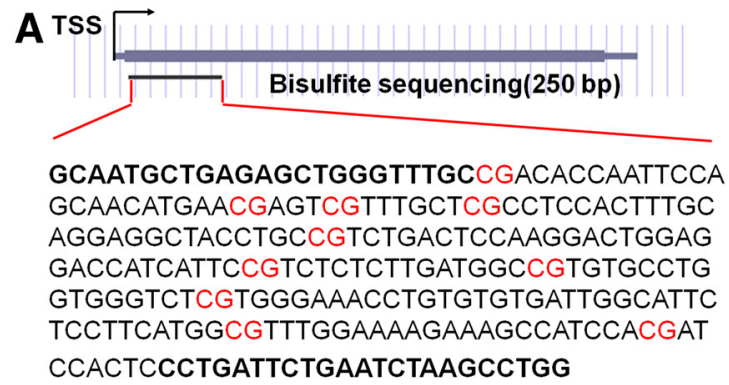

A TSS

B

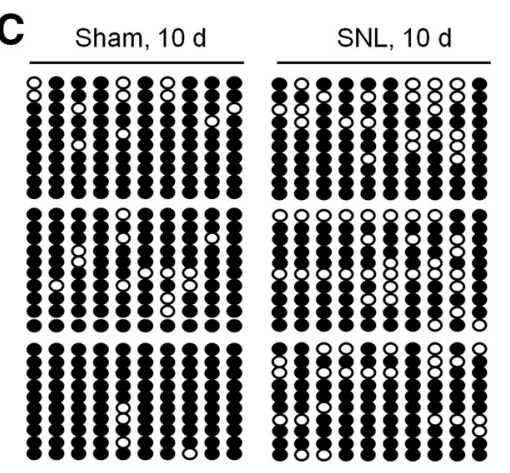

$\mathbf{F}$

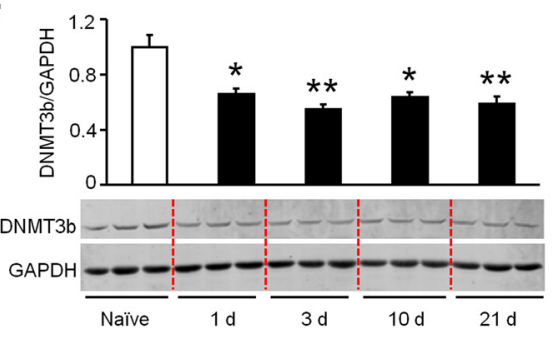

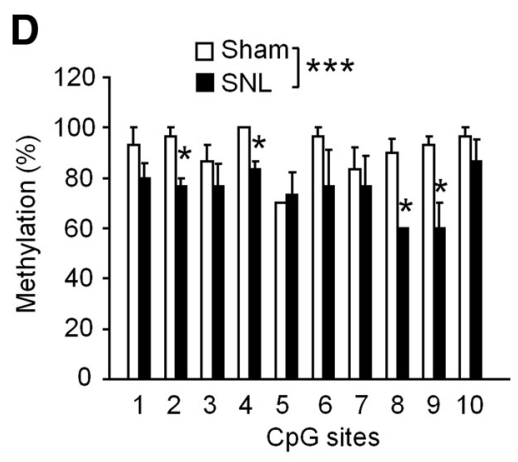
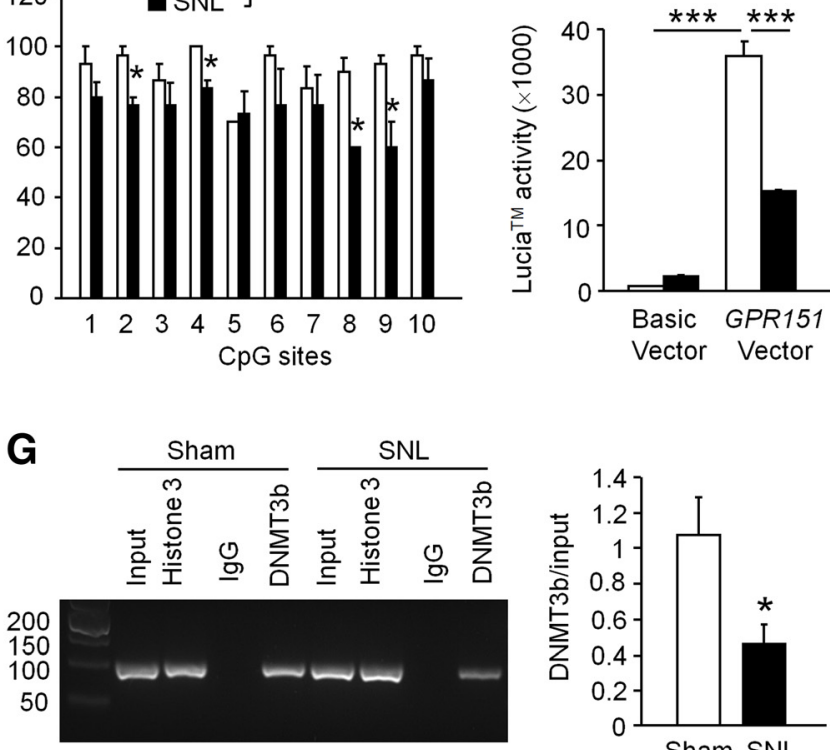

E $\quad$ QUnmethylated Methylated

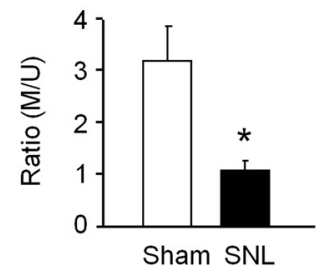

Vector Vector
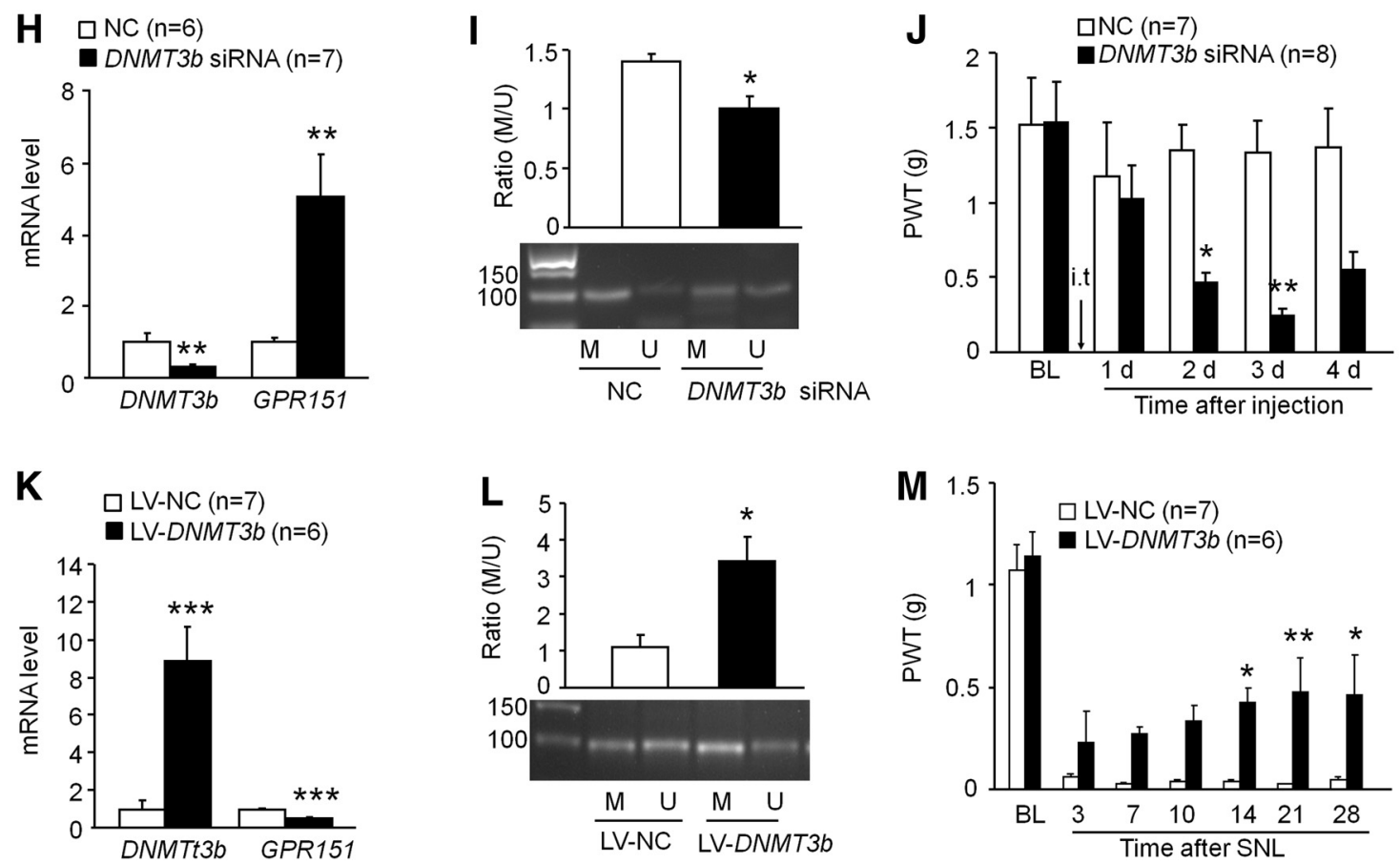

Figure 5. Demethylation of GPR151 gene promoter region after SNL. A, The schematic shows the location of 10 CpG sites (red) within a CpG island of the GPR151 gene promoter region. $B$, Representative PCR shows that the ratio of methylated (M) to unmethylated (U) amplification products was reduced after SNL. * $p<0.05$, versus sham. Student's $t$ test. $n=4$ mice/group. C, BSP of GPR151 promoter region of the spinal dorsal horn in sham- or SNL-operated mice. $n=3$ mice/group. Ten clones were randomly selected from each mouse. Filled circles, Methylated CpG sites; unfilled circles, unmethylated $\mathrm{CpG}$ sites. $\boldsymbol{D}$, The total methylation of GPR151 promoter was decreased after SNL. ${ }^{*} p<0.05,{ }^{* * *} p<0.001$, SNL versus sham. Two-way RM ANOVA followed by Bonferroni's tests. $n=3$ mice/group. $\boldsymbol{E}$, Coelenterazine-using luciferase assay shows that the luciferase activity was increased when using HEK-293 cells transfected (Figure legend continues.) 


\section{DNMT3b is decreased after SNL and negatively regulates GPR151 expression and neuropathic pain}

DNMTs, including DNMT1, DNMT3a, and DNMT3b, are important in directly regulating DNA methylation (Jurkowska et al., 2011). We previously found that the mRNA of DNMT3b, but not DNMT1 or DNMT3a, was decreased in the spinal cord after SNL (Jiang et al., 2017). Western blot showed that DNMT3b protein level was persistently reduced at Days $1,3,10$, and 21 after SNL $\left(F_{(4,14)}=0.08, p=0.003\right.$, one-way ANOVA; Fig. $\left.5 F\right)$. ChIP-PCR further showed that, after DNMT3b antibody immunoprecipitation, GPR151 has lower enrichment of DNMT3b occupancy in the spinal cord of SNL mice compared with sham-treated mice $(p=0.032$, Student's $t$ test; Fig. $5 G)$, indicating that the binding of DNMT3b with the GPR151 promoter is specific and is also reduced by SNL. These data also suggest that the downregulated DNMT3b may be responsible for the demethylation of the GPR151 promoter in neuropathic pain condition.

We then asked whether genetic silencing of DNMT3b activity could increase GPR151 expression in naive mice. Indeed, intrathecal administration of DNMT3b siRNA not only decreased the spinal DNMT3b mRNA level ( $p=0.010$, Student's $t$ test), also dramatically increased GPR 151 mRNA expression $3 \mathrm{~d}$ after injection $(p=0.009$, Student's $t$ test; Fig. $5 H)$. Meanwhile, the methylation level of the GPR151 promoter was reduced ( $p=0.007$, Student's $t$ test; Fig. $5 I$ ). The behavioral study showed that intrathecal injection of DNMT3b siRNA in naive mice induced mechanical allodynia at Days 2 and 3 after treatment $\left(F_{(1,65)}=17.37\right.$, $p=0.000$, two-way RM ANOVA; Fig. $5 J$ ). Based on the behavioral results, we further checked the mRNA level of DNMT3 $b$ and GPR151 2 and $4 \mathrm{~d}$ after siRNA injection. The results showed that DNMT3b mRNA was decreased [0.62 \pm 0.08 (DNMT3b siRNA) vs $1 \pm 0.12(\mathrm{NC}), p=0.027]$ and GPR151 mRNA was increased at Day $2[1.36 \pm 0.14$ (DNMT3b siRNA) vs $1 \pm 0.02(\mathrm{NC}), p=$ 0.030 , Student's $t$ test, $n=5$ mice/group], but not at Day 4 [DNMT3b: $0.78 \pm 0.10$ (DNMT3b siRNA) vs $1 \pm 0.10(\mathrm{NC}), p=$ 0.139; GPR151: $0.88 \pm 0.08$ (DNMT3b siRNA) vs $1 \pm 0.03$ (NC), $p=0.182$, Student's $t$ test, $n=5$ mice/group]. Furthermore, intraspinal injection of DNMT3b-expressing lentivirus (LV$D N M T 3 b)$ effectively increased DNMT3b expression $(p=0.001$, Student's $t$ test; Fig. $5 K)$, reduced GPR151 expression ( $p=0.000$, Student's $t$ test; Fig. $5 K)$, and increased the methylation of GPR151 promoter ( $p=0.016$, Student's $t$ test; Fig. $5 L)$. Consistently, injection of LV-DNMT3b $3 \mathrm{~d}$ before SNL alleviated SNLinduced mechanical allodynia at Days 14, 21, and 28 after SNL $\left(F_{(1,77)}=34.47, p=0.000\right.$, two-way RM ANOVA; Fig. $\left.5 M\right)$.

\section{$\leftarrow$}

(Figure legend continued.) with the unmethylated pCpG-free-GPR151-promoter-Lucia vector. ${ }^{* * *} p<0.001$. Student's $t$ test. $n=4$ /group. $\boldsymbol{F}$, Western blot shows that DNMT3b protein level was decreased after SNL. ${ }^{*} p<0.05$; ${ }^{* *} p<0.01$, versus naive. $n=3$ mice/group. $\boldsymbol{G}$, ChIP-PCR shows that the binding of DNMT3b with GPR151 in the spinal dorsal horn was decreased after SNL. ${ }^{*} p<0.05$, Student's $t$ test. $n=5$ mice/group. $\boldsymbol{H}$, The mRNA expression of DNMT3b was decreased and GPR151 was increased $2 \mathrm{~d}$ after intrathecal injection of DNMT3b siRNA. ${ }^{* *} p<0.01$, versus NC. Student's t test. $n=6-7$ mice/group. $I$, The ratio of methylated to unmethylated products of GPR151 promoter was decreased after intrathecal injection of DNMT3b siRNA. ${ }^{*} p<0.05$, versus NC. Student's $t$ test. $n=4$ mice/group. J, Intrathecal injection of DNMT3b siRNA induced mechanical allodynia. ${ }^{*} p<0.05,{ }^{* *} p<0.01$, versus NC. Twoway RM ANOVA followed by Bonferroni's tests. $n=7-8$ mice/group. $\boldsymbol{K}$, The mRNA expression of DNMT3b was increased and GPR151 was decreased after intraspinal infusion of LV-DNMT3b. ${ }^{* * *} p<0.001$, versus LV-NC. Student's $t$ test. $n=6-7$ mice/group. L, Pretreatment with LV-DNMT3b increased the methylation of GPR151 promoter in the spinal dorsal horn $10 \mathrm{~d}$ after SNL. ${ }^{*} p<0.05$, versus LV-NC. Student's $t$ test. $n=4$ mice/group. $M$, Intraspinal infusion of LV-DNMT3b, $3 \mathrm{~d}$ before SNL, alleviated SNL-induced mechanical allodynia. ${ }^{*} p<0.05$, ${ }^{* *} p<$ 0.01 , versus LV-NC. Two-way RM ANOVA followed by Bonferroni's tests. $n=6-7$ mice/group.
These data indicate the negative regulation of DNMT3b on GPR151 methylation and the involvement of DNMT3b in the pathogenesis of neuropathic pain.

\section{KLF5 leads to transactivation of the GPR151 gene promoter after SNL}

DNA methylation can regulate transcription by interfering with transcription factor binding (Poetsch and Plass, 2011). To reveal the transcriptional factors that may regulate GPR151 expression, the sequence from -1500 to +500 of GPR151 promoter was analyzed. Five KLF5 binding sites, two STAT3 binding sites, and two NFATC2 binding sites (Fig. $6 A-C$ ) were predicted within GPR151 promoter region based on JASPAR CORE in Vertebrata with a defined $80 \%$ profile score threshold (http://jaspar.genereg. net/). A conservation analysis using the UCSC genome browser showed that the five binding sites of KLF5 are well conserved among mouse, rat, and human (data not shown).

We then examined the binding of KLF5 with GPR151 promoter in the spinal cord dorsal horn after SNL by ChIP-PCR. After KLF5 antibody immunoprecipitation, the ChIP-PCR analysis revealed that GPR151 promoter has higher enrichment of KLF5 occupancy in the spinal cord of SNL mice compared with sham mice ( $p=0.030$, Student's $t$ test; Fig. $6 D$ ), indicating that the binding of KLF5 with the GPR151 promoter in the spinal cord is enhanced by SNL.

To determine the effect of KLF5 on GPR151 expression, we conducted a luciferase activity assay in vitro. KLF5-expressing vector and pCpG-free-GPR151-promoter-Lucia vector (methylated or unmethylated) were cotransfected. As shown in Figure $6 E$, in HEK293 cells transfected with methylated pCpG-freeGPR151-promoter-Lucia vector, cotransfection with KLF5expressing vector slightly increased the promoter luciferase activity, compared with the absence of KLF5-expressing vector. However, in these cells transfected with unmethylated pCpGfree-GPR151-promoter-Lucia vector, cotransfection of KLF5expressing vector dramatically increased the luciferase activity, compared with the absence of KLF5-expressing vector. In addition, KLF5 induced more luciferase activity increase in cells transfected with unmethylated pCpG-free-GPR151-promoter-Lucia vector than transfected with methylated one $\left(F_{(1,12)}=1030, p=\right.$ 0.000 , two-way ANOVA; Fig. $6 E$ ). These results suggest that KLF5 increases the transcription of the GPR151 gene, which is further enhanced when GPR151 promoter is demethylated.

To examine which binding site(s) of KLF5 on GPR151 promoter is essential for GPR151 gene expression, we made sitedirected mutagenesis of putative KLF5 consensus binding sites for the GPR151 promoter (Fig. $6 F)$. KLF5 vector $(0.5 \mu \mathrm{g} /$ well in 6-well plates) was cotransfected into HEK293 cells with mutant constructs and Renilla. The results from promoter assays showed that mutation of BS1, BS2, or BS5 did not significantly change the transcription activity of KLF5, but mutation of BS3 or BS4 almost completely blocked the transactivation effect of $\operatorname{KLF} 5\left(F_{(6,27)}=\right.$ 11.99, $p=0.000$, one-way ANOVA; Fig. $6 F$ ). These results further confirm that KLF5 facilitates the upregulation of GPR151, and also suggest that the third and fourth KLF5 binding sites in the GPR151 promoter are responsible for KLF5-mediated transcriptional activation.

\section{SNL increases KLF5 expression in spinal neurons}

We then examined KLF5 expression in the spinal cord dorsal horn after SNL. RT-PCR showed that KLF5 mRNA was significantly increased at Days $1,3,10$, and 21 after $\operatorname{SNL}\left(F_{(4,28)}=7.585\right.$, $p=0.000$, one-way ANOVA; Fig. 7A). Immunostaining showed 

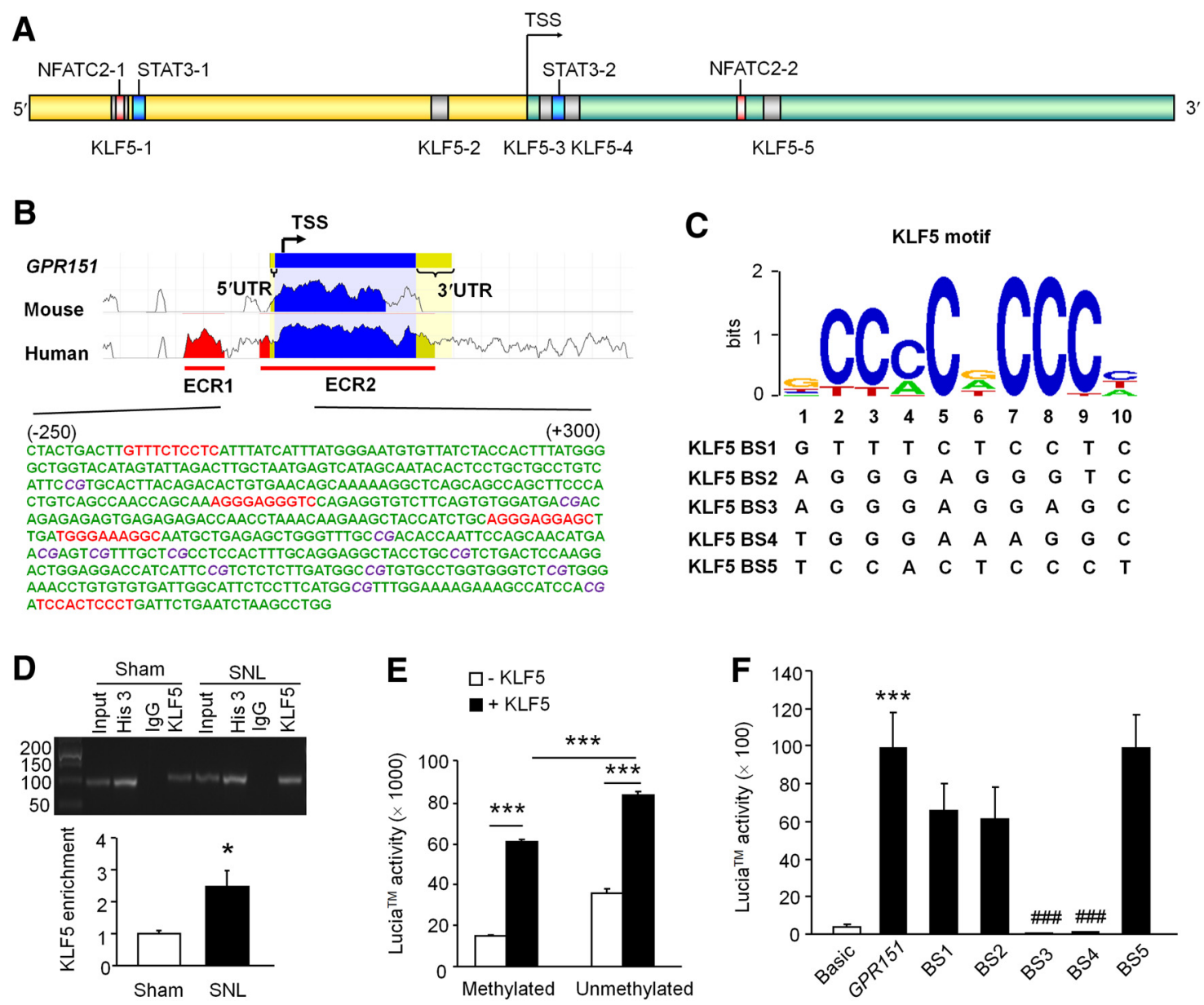

Figure 6. The transcription factor KLF5 promotes the expression of GPR151. A, Schematic representation of GPR151 promoter region. Putative binding sites for KLF5, STAT3, and NFATC2 transcription factors are shown. $\boldsymbol{B}$, The schematic shows the location of potential binding sites (red) of KLF5 with the GPR151 promoter region within the CpG sites. ECR, evolutionarily conserved regions. C, The logos of the standard KLF5 motif and five potential binding sites of KLF5 with GPR151 promoter (BS1-5). D, ChIP-PCR shows that the binding of KLF5 with GPR151 was increased after SNL. ${ }^{*} p<0.05$, versus sham. Student's $t$ test. $n=4$ mice/group. $E$, Coelenterazine-using luciferase assay shows that the luciferase activity was dramatically increased when KLF5-expressing vector was transfected with unmethylated pCpG-free-GPR151-promoter-Lucia vector in HEK293 cells. ${ }^{* * *} p<0.001$. Student's ttest. $n=4$ /group. $\boldsymbol{F}$, The luciferase reporter assay shows that the luciferase activity was decreased when cotransfection of KLF5-expressing vector with mutant KLF5 BS3 or BS4. ${ }^{* * *} p<0.001$, versus basic vector. \#\#\#p $<0.001$, versus GPR151 vector. One-way ANOVA. $n=$ 4/group.

that KLF5 had a low basal expression in the superficial dorsal horn in naive mice (Fig. $7 B$ ), and was markedly increased in the ipsilateral dorsal horn $10 \mathrm{~d}$ after SNL (Fig. 7C). In addition, the KLF5-positive signal was mostly colocalized with NeuN (Fig. 7D), partially with GFAP (Fig. 7E), but not with CD11b (Fig. 7F) in the dorsal horn of spinal cord. Furthermore, KLF5 is highly colocalized with GPR151 (Fig. 7G). The staining of KLF5 on the sections from $S S T-\mathrm{GFP}^{+}$or $G A D 67-\mathrm{GFP}^{+}$mice showed that KLF5 is expressed in SST-GFP ${ }^{+}$neurons (Fig. $7 H$ ) and GAD67$\mathrm{GFP}^{+}$neurons (Fig. 7I). These data indicate the predominant expression of KLF5 in GPR151 ${ }^{+}$neurons.

KLF5 siRNA attenuates SNL-induced pain hypersensitivity and decreases GPR151 expression in the spinal cord

To determine whether KLF5 plays a role in the maintenance of SNL-induced neuropathic pain, we intrathecally injected KLF5 or NC siRNA $10 \mathrm{~d}$ after SNL. Behavioral data showed that KLF5 siRNA dramatically attenuated SNL-induced mechanical allodynia from 6 to $24 \mathrm{~h}$ after injection $\left(F_{(1,66)}=9.93, p=0.002\right.$, two-way RM ANOVA; Fig. 7J). Meanwhile, KLF5 siRNA also attenuated SNL-induced heat hyperalgesia $\left(F_{(1,66)}=9.07, p=\right.$ 0.004 , two-way RM ANOVA; Fig. $7 K$ ). To examine the knock- down effect of KLF5 siRNA, we checked the mRNA level in another set of animals $24 \mathrm{~h}$ after SNL. As shown in Figure $7 L, K L F 5$ siRNA reduced KLF5 ( $p=0.034$, Student's $t$ test) and GPR151 mRNA ( $p=0.010$, Student's $t$ test $)$ expression in the spinal cord.

To further confirm the role of KLF5 in neuropathic pain, ML264, a potent and selective KLF5 inhibitor, was intrathecally injected $10 \mathrm{~d}$ after SNL. ML264 at the dose of $1 \mathrm{nmol}$ did not affect mechanical allodynia, but $10 \mathrm{nmol}$ ML264 increased the threshold at $24 \mathrm{~h}\left(F_{(2,68)}=8.106, p=0.001\right.$, two-way RM ANOVA; Fig. $7 M)$. For the thermal test, ML264 at the dose of 1 nmol alleviated SNL-induced heat hyperalgesia at 24 and $48 \mathrm{~h}$ (Fig. 7N). The higher dose $(10 \mathrm{nmol})$ reversed SNL-induced heat hyperalgesia at $24 \mathrm{~h}\left(F_{(2,68)}=24.5, p=0.000\right.$, two-way RM ANOVA; Fig. $\left.7 N\right)$. The treatment also reduced the expression of KLF5 and GPR151 (Fig. 7O). These results suggest that KLF5 regulates GPR151 expression and is involved in SNL-induced neuropathic pain.

Mutation of GPR151 decreases the expression of MAPK pathway-related genes and the activation of ERK in the spinal cord after SNL

To investigate the downstream signaling of GPR151 activation, we performed microarray to compare gene expression in the spi- 

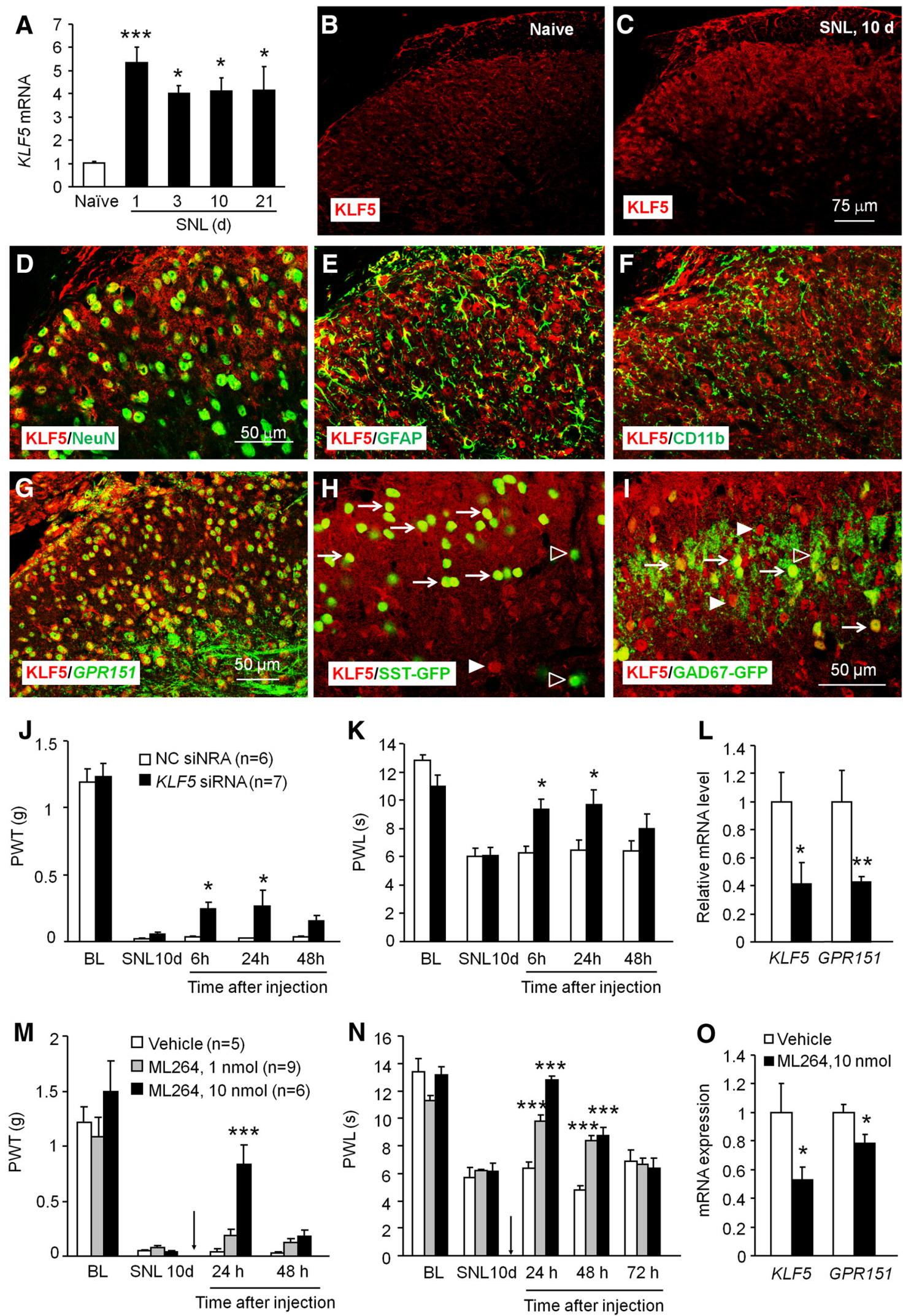

Figure 7. KLF5 is increased in the spinal cord after SNL and contributes to SNL-induced neuropathic pain. $A$, The time course of KLF5 mRNA expression in the spinal cord from naive and SNL-operated mice. The mRNA expression of KLF5 was increased at Days $1,3,10$, and 21 after SNL. ${ }^{*} p<0.05{ }^{* * *} p<0.001$, SNL versus naive. One-way ANOVA. $n=5-6$ mice/group. $B$, $C$, Representative images of KLF5 immunofluorescence in the spinal cord from naive and SNL mice. KLF5 was constitutively expressed in naive mice (B), and increased in SNL-operated mice (C). $\boldsymbol{D}-\boldsymbol{F}$, Double-immunofluorescence staining shows that KLF5 was mainly colocalized with the neuronal marker NeuN (D), a few with astrocyte marker GFAP (E), none with microglia marker CD11b $(\boldsymbol{F})$ in the dorsal horn of spinal cord $10 \mathrm{~d}$ after SNL. G, In situ hybridization of GPR 151 and immunostaining with KLF5 in the spinal cord $10 \mathrm{~d}$ after SNL. H, I, Immunostaining of KLF5 on the spinal cord from SST-GFP $(\boldsymbol{H})$ and GAD67-GFP $(\boldsymbol{I})$ mice $10 \mathrm{~d}$ after SNL. Arrows show typical double-staining neurons. Filled triangles show typical KLF5-single-labeled neurons. Blank triangles show SST- (in $\boldsymbol{H}$ ) or GAD67-single-labeled (in $\boldsymbol{I}$ ) neurons. J, $\boldsymbol{K}$, Intrathecal injection of KLF5 siRNA alleviated SNL-induced mechanical allodynia $(\boldsymbol{J})$ and heat hyperalgesia $(\boldsymbol{K}) .{ }^{*} p<0.05$, (Figure legend continues.) 

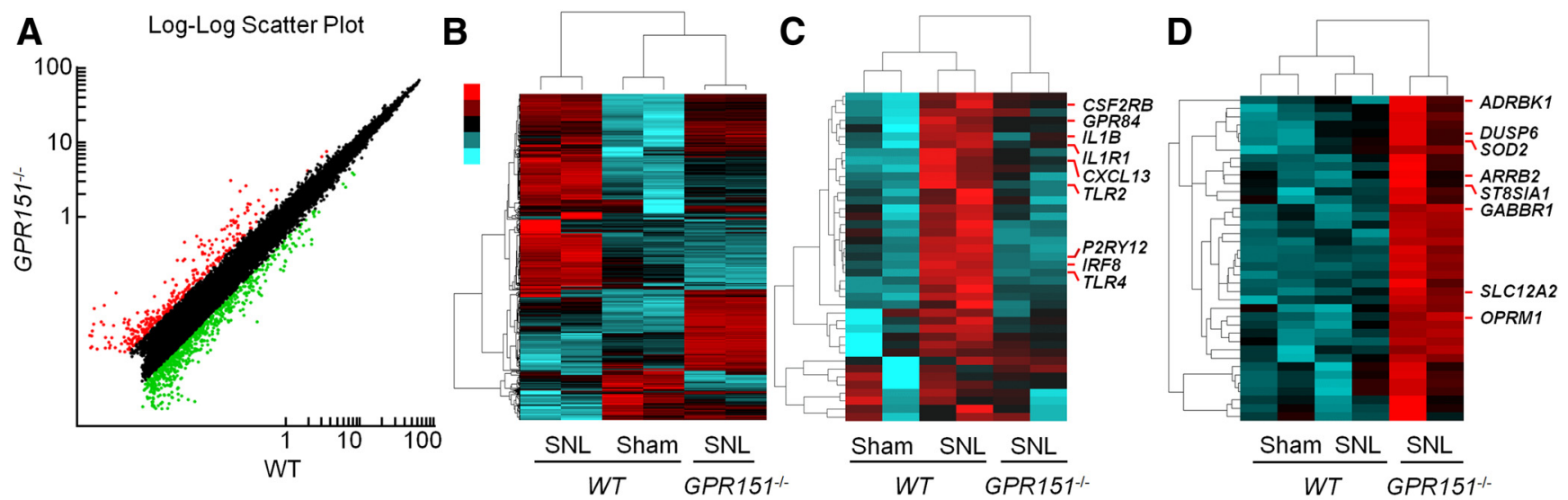

$\mathbf{E}$

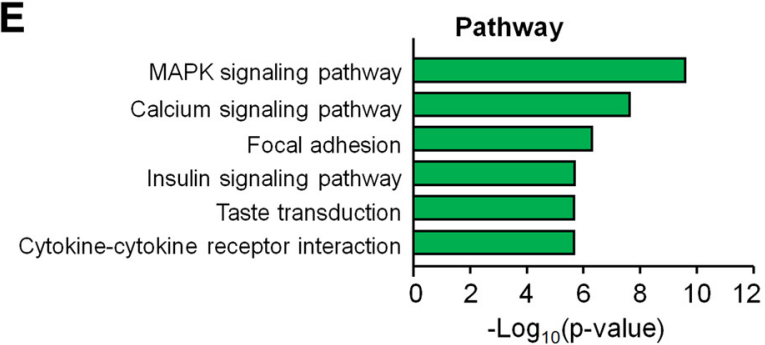

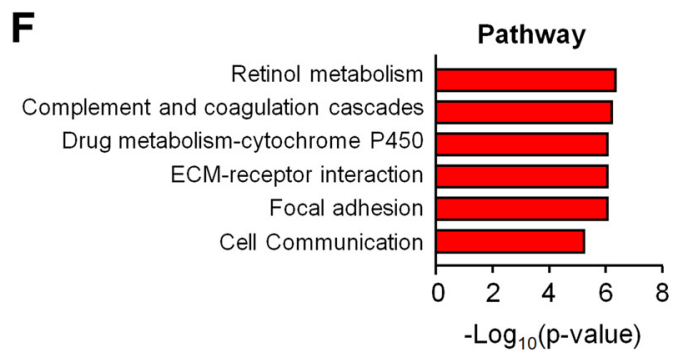

G

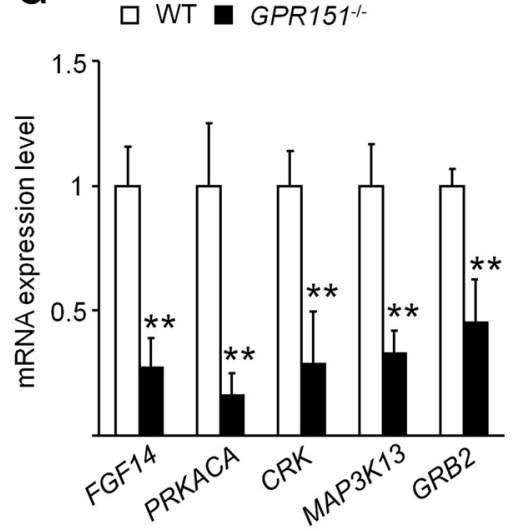

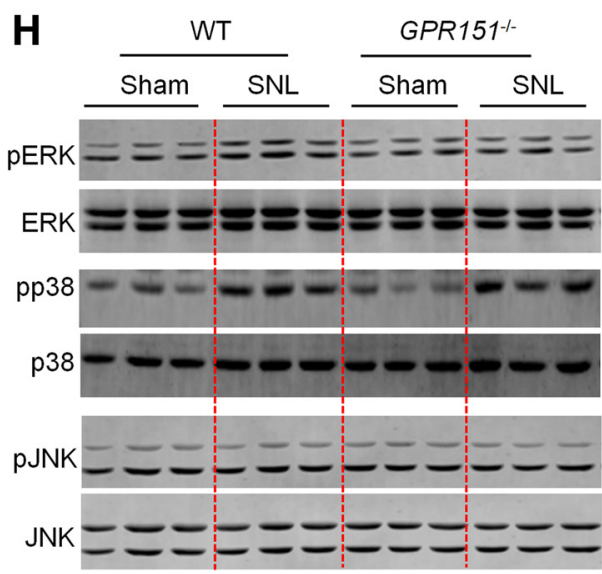
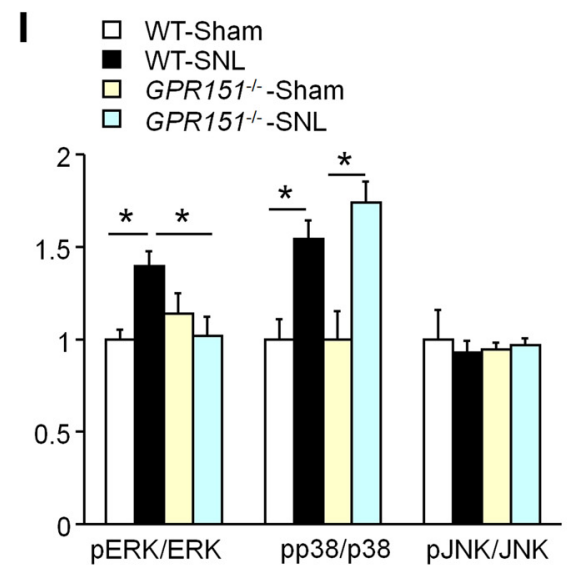

Figure 8. Gene expression profiles in the spinal cord of WT and GPR151 deficient mice after SNL. A, A scatter plot shows the gene expression in WT and GPR151 ${ }^{-1-}$ mice. Red dots represent upregulated genes, and green dots represent downregulated genes. $\boldsymbol{B}$, Heat map of expression of differentially expressed genes whose expression changes were $>2$-fold in SNL group compared with the sham group. A dendrogram (top) shows the clustering of the samples regarding these expression values $(n=2 /$ group). $C$, Heat map representing expression values of 41 pain-related genes from Pain Gene database that were upregulated by nerve injury and normalized to the sham control after GPR151 mutation. D, Heat map representing expression values of 39 pain-related genes from the Pain Gene database that were upregulated in SNL GPR151-/- group compared with the WT-SNL group. $E$, The significant pathways for downregulated genes in GPR151 ${ }^{-1-}$-SNL group. The MAPK pathway-associated genes were downregulated dramatically in GPR151 ${ }^{-/-}-$SNL mice compared with WT-SNL mice. $\boldsymbol{F}$, The significant pathways for upregulated genes in GPR151 mutation group. G, RT-PCR for FGF14, PRKACA, CRK, MAP3K13, and GRB2 gene expression levels in WT and GPR151 ${ }^{-I-}$ mice $10 \mathrm{~d}$ after SNL. ${ }^{* *} p<0.01$. Student's $t$ test, $n=4$ mice/group. $\boldsymbol{H}, \boldsymbol{I}$, Western blots for pERK, pp38, and pJNK in the spinal cord from WT and GPR151 ${ }^{-I-}$ mice $10 \mathrm{~d}$ after sham or SNL operation. ${ }^{*} p<0.05$, Student's $t$ test, $n=3$ mice/group.

(Figure legend continued.) versus NC siRNA. Two-way RM ANOVA followed by Bonferroni's tests. $n=6-7$ mice/group. $L$, The mRNA expression of $K L F 5$ and GPR151 were decreased after intrathecal injection of $K L F 5$ siRNA. ${ }^{*} p<0.05,{ }^{* *} p<0.01$, versus NC siRNA. Student's $t$ test. $n=6-8$ mice/group. $\boldsymbol{M}, \boldsymbol{N}$, Intrathecal injection of KLF5 inhibitor, ML264, $10 \mathrm{~d}$ after SNL alleviated SNL-induced mechanical allodynia $(\boldsymbol{M})$ and thermal hyperalgesia $(\boldsymbol{M}) .{ }^{* * *} p<0.001$, versus Vehicle. Two-way RM ANOVA followed by Bonferroni's tests. $n=5-9$ mice/group. $\mathbf{O}$, The mRNA expression of KLF5 and GPR151 was decreased after intrathecal injection of ML264. ${ }^{*} p<0.05$, versus vehicle, Student's $t$ test. $n=7-9$ mice/group. nal cord of GPR $151^{-1-}$ and WT mice. First, we obtained a graphical overview of the expression signatures of mRNAs using a scatter plot. It showed that a large number of mRNAs were differentially expressed between GPR $151^{-1-}$ and WT mice (Fig. $8 A$ ). In the differentially expressed mRNAs, there were 616 genes whose mRNA change was $>1.5$-fold. Among them, 389 genes were downregulated, and 227 genes were upregulated in GPR $151^{-1-}$ mice. The heat map generated with the values for all the differentially expressed genes showed that GPR $151^{-/-}-\mathrm{SNL}$ and WT-Sham samples clustered together (Fig. $8 B$ ), suggesting that the transcript values for GPR $151^{-1-}$-SNL mice were closer 
A

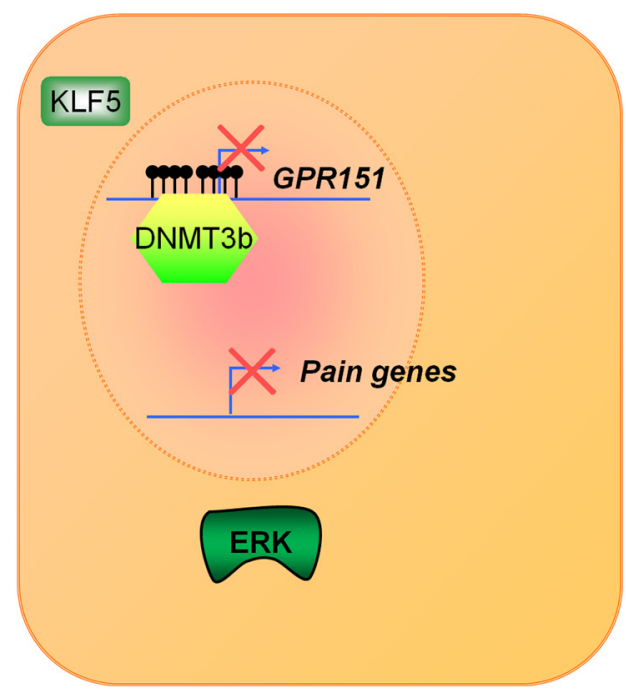

B Neuropathic pain

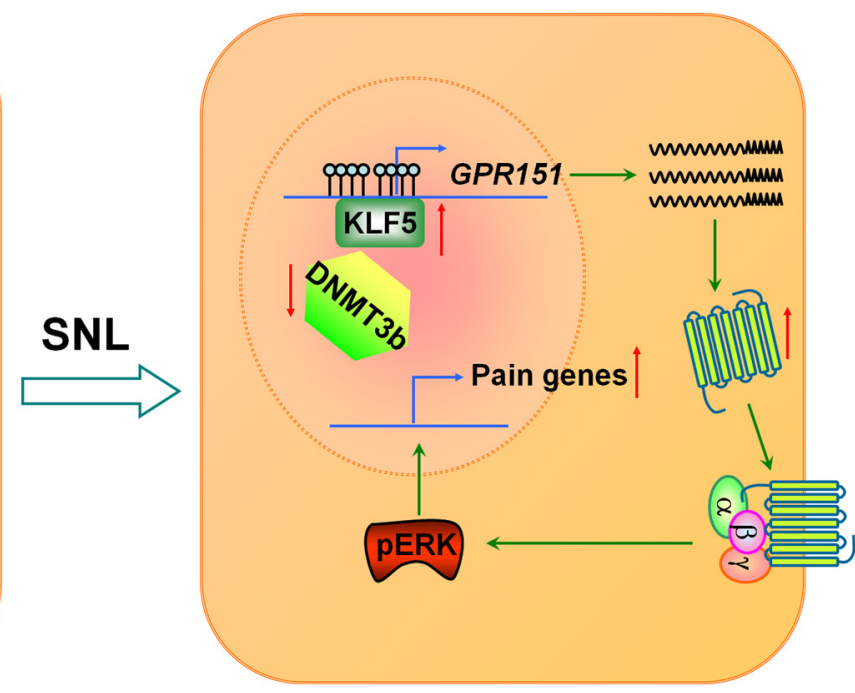

Figure 9. Schematic shows the epigenetic regulation of GPR151 expression and the mechanism of GPR151 underlying neuropathic pain. $\boldsymbol{A}$, In healthy spinal cord, DNMT3b binds to the GPR151 promoter and silences its expression through DNA methylation. $\boldsymbol{B}$, After nerve injury, DNMT3b dissociates from the GPR151 gene promoter following by active DNA demethylation, which induces chromatin accessibility, thereby promotes the recruitment of the transcriptional machinery. The transcription factor KLF5 is recruited onto the GPR151 gene promoter, facilitates GPR151 transcription, and further increases the expression of GPR151 protein. The increased GPR151 on the membrane is activated by extracellular signals and induce the activation of ERK. The pERK translocates into the nucleus and induces the expression of multiple algogenic genes that participate in pain processing, leading to the pathogenesis of neuropathic pain.

to the values obtained from WT-sham mice than those from WT-SNL mice. We further performed cluster analysis of expression values for the set of pain-related genes from Pain Gene Database (Lacroix-Fralish et al., 2007). Expression levels of multiple genes in the algogenic pain processing pathway were decreased in GPR151 1 -I- SNL mice compared with WT-SNL group. These genes include colony stimulating factor 2 receptor $\beta$ common subunit $(C S F 2 R B)$, interleukin $1 \beta(I L 1 B)$, interleukin 1 receptor type 1 (IL1R1), G-protein-coupled receptor 84 (GPR84), C-X-C motif chemokine ligand 13 (CXCL13), toll-like receptor 2 (TLR2), toll-like receptor 4 (TLR4), purinergic receptor P2Y12 (P2RY12), and interferon regulatory factor 8 (IRF8; Fig. 8C). Several analgesic genes were increased in GPR $151^{-1-}$-SNL mice, including G-protein-coupled receptor kinase 2 (GRK2), dual specificity phosphatase 6 (DUSP6), superoxide dismutase 2 (SOD2), arrestin $\beta 2$ (ARRB2), ST8 $\alpha$-N-acetyl-neuraminide $\alpha$-2, 8-sialyltransferase 1 (ST8SIA1), gamma-aminobutyric acid type B receptor subunit $1(G A B B R 1)$, opioid receptor $\mu 1$ (OPRM1), and solute carrier family 12 member 2 (SLC12A2; Fig. $8 D)$. These data suggest that mutation of GPR151 changes the expression of many genes associated with neuropathic pain.

To explore the molecular pathways mediated by GPR151 in the spinal cord, we performed KEGG pathway analysis. As shown in Figure 8E, KEGG analysis of downregulated genes showed that six KEGG pathways were downregulated in the absence of GPR151, including MAPK signaling, calcium signaling, focal adhesion, insulin signaling, taste transduction, and cytokinecytokine receptor interaction. Upregulated genes in GPR $151^{-1-}$ SNL mice involved retinol metabolism, complement and coagulation cascades, drug metabolism-cytochrome P450, ECMreceptor interaction, focal adhesion, and cell communication pathways (Fig. $8 F$ ). Based on the important role of MAPK signaling in neuropathic pain (Ji et al., 2009), we validated the MAPK signaling pathway genes by qPCR. We checked the expression of fibroblast growth factor 14 (FGF14; $p=0.01$, Student's $t$ test), protein kinase cAMP-activated catalytic subunit $\alpha$ (PRKACA; $p=0.019$, Student's $t$ test), CRK proto-oncogene adaptor protein
$(C R K ; p=0.029$, Student's $t$ test $)$, mitogen-activated protein kinase kinase kinase 13 (MAP3K13; $p=0.012$, Student's $t$ test), and growth factor receptor bound protein 2 (GRB2; $p=0.025$, Student's $t$ test; Fig. $8 G$ ) and found that they were significantly reduced in the spinal cord of GPR $151^{-1-}$ mice compared with that in WT mice (Fig. 8G). We also assessed levels of phosphorylation of the three MAPK family members: extracellular signalregulated kinase (ERK), p38, and c-Jun N-terminal kinase (JNK; Fig. $8 H, I$ ). Interestingly, the phosphoERK (pERK) was substantially inhibited by GPR151 ablation ( $p=0.043, G P R 151^{-/-}$-SNL vs WT-SNL, Student's $t$ test), and pp38 expression was increased in both WT and GPR151 ${ }^{-1-}$ mice $(p=0.021$, WT-SNL vs WTSham; $p=0.017$ GPR151 $1^{-/-}$-SNL vs GPR151 $1^{-/-}$-Sham, Student's $t$ test), whereas pJNK expression was not changed after SNL in both WT and GPR151 $1^{-1-}$ mice ( $p=0.693$, WT-SNL vs WT-Sham; $p=0.688, G P R 151^{-1-}$-SNL vs GPR $151^{-/-}$-Sham, Student's $t$ test). The above results suggest that GPR151 may contribute to the maintenance of neuropathic pain via downregulating algogenic genes, especially MAPK signaling pathwayrelated genes.

\section{Discussion}

The development and maintenance of neuropathic pain is a process involving morphological, functional, and transcriptional changes in the nervous system. The mechanisms and the key transcriptional regulators controlling the pain-related gene expression are not well understood on the molecular level. Emerging evidence showed that orphan GPCRs are involved in the initiation and progression of neuropathic pain (Nicol et al., 2015; Li et al., 2017b). Our results strongly suggest that spinal GPR151 contributes to neuropathic pain genesis. Mechanistically, SNL increases GPR151 expression by decreasing DNMT3b expression, preventing the maintenance of promoter DNA methylation, and increasing KLF5 expression and recruitment. Additionally, the increased GPR151 may participate in neuropathic pain via activating the MAPK pathway and increasing al- 
gogenic pain gene expression (Fig. 9). Thus, our results reveal a significant role of GPR151 in mediating neuropathic pain and the epigenetic mechanism underlying GPR151 expression.

GPCRs are the predominant receptors of neuromodulators and regulate a wide range of nervous system disorders and diseases including anxiety, schizophrenia, epilepsy, Alzheimer's disease, Parkinson's disease, and chronic pain (Baulac et al., 2001; Ahmed et al., 2010; Gaillard et al., 2014; Masseck et al., 2014; Hao et al., 2015; Foster and Conn, 2017; Xie et al., 2018). Approximately 100 orphan GPCRs have been identified to be potential targets for the therapeutics of nervous system diseases (Civelli, 2012). Although the search for their endogenous ligands has been a challenge, the development of molecular biology and gene knock-out techniques made the identification of orphan GPCR functions amenable (Cui et al., 2016; Chang et al., 2017; Khrimian et al., 2017). Several studies have recently demonstrated that orphan GPCRs in the spinal cord are critical players in the induction and maintenance of pathological pain (Nicol et al., 2015; Li et al., 2017b). Especially, GPR84 is increased in the sciatic nerve and spinal cord after partial sciatic ligation, mediates pain hypersensitivity via the modulation of peripheral macrophage response (Nicol et al., 2015). Consistent with this observation, our data also revealed the increase of GPR84 in the spinal cord after SNL. Interestingly, among all the detected GPCR genes, GPR151 was the most markedly increased GPCR with a 26-fold increase. qPCR confirmed the increase of GPR151 from Days 3 to 21 after SNL. Previous studies have shown that GPR151 was exclusively expressed in neurons of habenula (Kobayashi et al., 2013; Broms et al., 2015). Our results also showed predominant expression of GPR151 in neurons of lamina I-IV of the dorsal horn. Furthermore, GPR151 was expressed in both $\mathrm{SST}^{+}$-excitatory neurons and $\mathrm{GAD} 7^{+}$-inhibitory neurons in lamina II. Recent studies showed that ablation of $\mathrm{SST}^{+}$neurons causes loss of mechanical pain, whereas ablation of dynorphin neurons $\left(>80 \%\right.$ in GAD67 ${ }^{+}$ neurons) induces spontaneous mechanical allodynia (Duan et al., 2014). Taken with the behavioral results (Fig. 4B-E), we speculate that GPR151 in excitatory neurons of lamina II and projection neurons of lamina I, and III-IV may play a significant role in the pathogenesis of neuropathic pain, which needs further investigation.

Behavioral studies showed that GPR151 mutation did not affect basal pain, which is consistent with the recent report (Holmes et al., 2017). However, Holmes et al. (2017) showed that GPR151 was highly upregulated after SNI, but deletion of GPR151 did not affect SNI-induced neuropathic pain. It is possible that different gene mutation strategy (deletion mutation vs insertion mutation) or different nerve injuries used (SNL vs SNI) affects the phenotype, and GPR151 in the DRG may not contribute to neuropathic pain. We used LV-GPR151 shRNA to specific knockdown GPR151 in the spinal cord and found that SNLinduced mechanical allodynia was persistently attenuated and even the second injection of LV-GPR151 shRNA was still effective in reversing late-phase neuropathic pain. These data support the involvement of spinal GPR151 in the development and maintenance of neuropathic pain.

A growing body of evidence has suggested that aberrant epigenetic changes are one of the most frequent events and are regarded as important mechanisms in neuropathic pain (Z. Zhang et al., 2011; Imai et al., 2013; Hong et al., 2015; Laumet et al., 2015). DNA demethylation has an essential role in regulating pain-related gene expression (H. H. Zhang et al., 2015; Jiang et al., 2017; Zhao et al., 2017). We identified GPR151 as a novel preferentially demethylated gene after SNL. Moreover, the demethyl- ation of GPR151 is positively associated with the persistent decrease of DNMT3b in the spinal cord. Manipulation of DNMT3b expression by siRNA or overexpression lentivirus changed the DNA methylation level of the GPR151 promoter and GPR151 expression. DNMT3b is a crucial de novo methyltransferase, preferentially expressed in neurons within the nervous system (Pollema-Mays et al., 2014). Furthermore, DNMT3b can aggravate neurological disorders progression through demethylation of target genes' promoter by downregulation of itself (Das et al., 2010; Liu et al., 2016). Recent studies showed that DNMT3b was decreased in the DRG and downregulated the methylation level of $P 2 X 3 R$ gene promoter and enhanced interaction with $\mathrm{NF} \kappa \mathrm{B}$ in cancer pain and diabetes pain models in rats $(\mathrm{H} . \mathrm{H}$. Zhang et al., 2015; Zhou et al., 2015). Our previous work demonstrated that the expression of DNMT3b mRNA was remarkably downregulated in the spinal cord in SNL mice, which contributed to the demethylation of chemokine receptor CXCR3 promoter (Jiang et al., 2017). Therefore, SNL-induced downregulation of DNMT3b in the DRG and spinal cord may affect the expression of a variety of genes, including GPR151.

DNA methylation and transcription factors usually work together to regulate gene expression (H. H. Zhang et al., 2015; Guhathakurta et al., 2017; Li et al., 2017a; Yu et al., 2017). Under physiological conditions, several transcription factors, such as Runx1, IRF5, C/EBP $\beta$, ZFHX2, have been demonstrated to participate in the gating of pain via activating the expression of nociceptive genes (Lou et al., 2013; Masuda et al., 2014; Habib et al., 2017; Qi et al., 2017). We showed that following SNL, KLF5 was increased in the spinal neuron, and contributed to GPR151 upregulation via direct binding to the promoter loci of GPR151 and increasing its transcription. KLF5 is a member of the large KLF family of transcription factors and has been found localized in the neurons of hippocampus and hypothalamus, where it plays vital parts in the pathogenesis of schizophrenia and food intake, respectively (Yanagi et al., 2008; Moore et al., 2011; Kojima et al., 2013). Previous reports have shown that inhibiting KLF6, KLF9, and KLF15 by DNA decoys produces a long-term pain treatment in rat models of neuropathic pain (Mamet et al., 2017). We provide the first evidence that inhibition of KLF5 through intrathecal injection of siRNA or chemical inhibitor effectively attenuated pain hypersensitivity and inhibited GPR151 increase. In addition, DNMT3b-mediated DNA demethylation is essential for the binding of KLF5 on the target sites in the GPR151 promoter. However, it is worth noting that KLF5 may also be involved in neuropathic pain via targeting genes other than GPR151 (Drosatos et al., 2016). GPR151 may also be regulated by other transcription factors, such as STAT3, NFATC2, which also can bind on the GPR151 promoter.

Our array data revealed that mutation of GPR151 has a vital function in genome-wide gene-expression changes in the spinal cord caused by SNL. SNL changes the expression of a vast amount of functional genes, such as ion channels, GPCRs, and kinases in the spinal cord (LaCroix-Fralish et al., 2011; Jiang et al., 2015). Notably, our transcriptome analysis data showed that mutation of GPR151 normalized the expression profile of differentially expressed genes after nerve injury. Moreover, mutation of GPR151 downregulated algogenic genes' expression and upregulated analgesic genes' expression after nerve injury, which may contribute to the reduced hypersensitivity to mechanical or thermal stimuli. GPR151 mutation also impaired the expression of MAPK signaling pathway associated genes FGF14, PRKACA, CRK, MAP3K13, and GRB2 in the spinal cord after SNL. These genes may decrease the signal intensity of MAPK signaling pathway. Several lines of 
evidence strongly suggest that spinal MAPK signaling play a pivotal role in the development of inflammatory and neuropathic pain (Ji et al., 2009; Edelmayer et al., 2014). Previous reports have shown that P38 and JNK are respectively activated in spinal microglia and astrocytes, whereas ERK is activated in spinal neurons, astrocytes, and microglia after nerve injury in rats (Jin et al., 2003; Zhuang et al., 2005, 2006; Jiang et al., 2016). Our Western blot data showed that SNL-induced p38 activation was not affected by GPR151 ablation, and JNK was not activated in C57BL/6 background WT mice and GPR $151^{-1-}$ mice after SNL. However, SNL-induced ERK was substantially inhibited by GPR151 ablation, suggesting that ERK is an important downstream of GPR151. In addition, ERK has been identified to be a downstream kinase of Gai-subunit containing GPCRs (Goldsmith and Dhanasekaran, 2007). Whether GPR151 is a Gaicoupled receptor needs further investigation.

In conclusion, we provide the first evidence that SNL increased GPR151 expression via DNMT3b-mediated demethylation of the GRP151 promoter and KLF5-mediated increase of GPR151 transcription. Also, GPR151 contribute to the maintenance of neuropathic pain, probably via activating the ERK signaling pathway. Thus, GPR151 may be a potentially novel therapeutic target for the alleviation of neuropathic pain.

\section{References}

Abbadie C, Lindia JA, Cumiskey AM, Peterson LB, Mudgett JS, Bayne EK, DeMartino JA, MacIntyre DE, Forrest MJ (2003) Impaired neuropathic pain responses in mice lacking the chemokine receptor CCR2. Proc Natl Acad Sci U S A 100:7947-7952. CrossRef Medline

Ahmed MR, Berthet A, Bychkov E, Porras G, Li Q, Bioulac BH, Carl YT, Bloch B, Kook S, Aubert I, Dovero S, Doudnikoff E, Gurevich VV, Gurevich EV, Bezard E (2010) Lentiviral overexpression of GRK6 alleviates L-dopainduced dyskinesia in experimental Parkinson's disease. Sci Transl Med 2:28ra28. CrossRef Medline

Anand P, Shenoy R, Palmer JE, Baines AJ, Lai RY, Robertson J, Bird N, Ostenfeld T, Chizh BA (2011) Clinical trial of the p38 MAP kinase inhibitor dilmapimod in neuropathic pain following nerve injury. Eur J Pain 15:1040-1048. CrossRef Medline

Baulac S, Huberfeld G, Gourfinkel-An I, Mitropoulou G, Beranger A, Prud'homme JF, Baulac M, Brice A, Bruzzone R, LeGuern E (2001) First genetic evidence of GABA(A) receptor dysfunction in epilepsy: a mutation in the gamma2-subunit gene. Nat Genet 28:46. CrossRef Medline

Broms J, Antolin-Fontes B, Tingström A, Ibañez-Tallon I (2015) Conserved expression of the GPR151 receptor in habenular axonal projections of vertebrates. J Comp Neurol 523:359-380. CrossRef Medline

Broms J, Grahm M, Haugegaard L, Blom T, Meletis K, Tingström A (2017) Monosynaptic retrograde tracing of neurons expressing the G-protein coupled receptor Gpr151 in the mouse brain. J Comp Neurol 525:32273250. CrossRef Medline

Buchen L (2012) Opioid receptors revealed. Nature 483:383. CrossRef Medline

Cedar H, Bergman Y (2012) Programming of DNA methylation patterns. Annu Rev Biochem 81:97-117. CrossRef Medline

Chang J, Mancuso MR, Maier C, Liang X, Yuki K, Yang L, Kwong JW, Wang J, Rao V, Vallon M, Kosinski C, Zhang JJ, Mah AT, Xu L, Li L, Gholamin S, Reyes TF, Li R, Kuhnert F, Han X, et al. (2017) Gpr124 is essential for blood-brain barrier integrity in central nervous system disease. Nat Med 23:450-460. CrossRef Medline

Civelli O (2012) Orphan GPCRs and neuromodulation. Neuron 76:12-21. CrossRef Medline

Cui J, Ding Y, Chen S, Zhu X, Wu Y, Zhang M, Zhao Y, Li TR, Sun LV, Zhao S, Zhuang Y, Jia W, Xue L, Han M, Xu T, Wu X (2016) Disruption of Gpr45 causes reduced hypothalamic POMC expression and obesity. J Clin Invest 126:3192-3206. CrossRef Medline

Das S, Foley N, Bryan K, Watters KM, Bray I, Murphy DM, Buckley PG, Stallings RL (2010) MicroRNA mediates DNA demethylation events triggered by retinoic acid during neuroblastoma cell differentiation. Cancer Res 70:7874-7881. CrossRef Medline
Dixon WJ (1980) Efficient analysis of experimental observations. Annu Rev Pharmacol Toxicol 20:441-462. CrossRef Medline

Drosatos K, Pollak NM, Pol CJ, Ntziachristos P, Willecke F, Valenti MC, Trent CM, Hu YY, Guo S, Aifantis I, Goldberg IJ (2016) Cardiac myocyte KLF5 regulates ppara expression and cardiac function. Circ Res 118: 241-253. CrossRef Medline

Duan B, Cheng L, Bourane S, Britz O, Padilla C, Garcia-Campmany L, Krashes M, Knowlton W, Velasquez T, Ren X, Ross SE, Lowell BB, Wang Y, Goulding M, Ma Q (2014) Identification of spinal circuits transmitting and gating mechanical pain. Cell 159:1417-1432. CrossRef Medline

Edelmayer RM, Brederson JD, Jarvis MF, Bitner RS (2014) Biochemical and pharmacological assessment of MAP-kinase signaling along pain pathways in experimental rodent models: a potential tool for the discovery of novel antinociceptive therapeutics. Biochem Pharmacol 87:390-398. CrossRef Medline

Foster DJ, Conn PJ (2017) Allosteric modulation of GPCRs: new insights and potential utility for treatment of schizophrenia and other CNS disorders. Neuron 94:431-446. CrossRef Medline

Gaillard S, Lo Re L, Mantilleri A, Hepp R, Urien L, Malapert P, Alonso S, Deage M, Kambrun C, Landry M, Low SA, Alloui A, Lambolez B, Scherrer G, Le Feuvre Y, Bourinet E, Moqrich A (2014) GINIP, a G $\alpha$ i-interacting protein, functions as a key modulator of peripheral GABAB receptormediated analgesia. Neuron 84:123-136. CrossRef Medline

Goldsmith ZG, Dhanasekaran DN (2007) G protein regulation of MAPK networks. Oncogene 26:3122-3142. CrossRef Medline

Guhathakurta S, Bok E, Evangelista BA, Kim YS (2017) Deregulation of $\alpha$-synuclein in Parkinson's disease: insight from epigenetic structure and transcriptional regulation of SNCA. Prog Neurobiol 154:21-36. CrossRef Medline

Habib AM, Matsuyama A, Okorokov AL, Santana-Varela S, Bras JT, Aloisi AM, Emery EC, Bogdanov YD, Follenfant M, Gossage SJ, Gras M, Humphrey J, Kolesnikov A, Le Cann K, Li S, Minett MS, Pereira V, Ponsolles C, Sikandar S, Torres JM, et al. (2017) A novel human pain insensitivity disorder caused by a point mutation in ZFHX2. Brain 141:365-376. Medline

Hao JR, Sun N, Lei L, Li XY, Yao B, Sun K, Hu R, Zhang X, Shi XD, Gao C (2015) L-Stepholidine rescues memory deficit and synaptic plasticity in models of Alzheimer's disease via activating dopamine D1 receptor/PKA signaling pathway. Cell Death Dis 6:e1965. CrossRef Medline

Hargreaves K, Dubner R, Brown F, Flores C, Joris J (1988) A new and sensitive method for measuring thermal nociception in cutaneous hyperalgesia. Pain 32:77-88. CrossRef Medline

Hauser AS, Chavali S, Masuho I, Jahn LJ, Martemyanov KA, Gloriam DE, Babu MM (2018) Pharmacogenomics of GPCR drug targets. Cell 172: 41-54.e19. CrossRef Medline

von Hehn CA, Baron R, Woolf CJ (2012) Deconstructing the neuropathic pain phenotype to reveal neural mechanisms. Neuron 73:638-652. CrossRef Medline

Holmes FE, Kerr N, Chen YJ, Vanderplank P, McArdle CA, Wynick D (2017) Targeted disruption of the orphan receptor Gpr151 does not alter painrelated behaviour despite a strong induction in dorsal root ganglion expression in a model of neuropathic pain. Mol Cell Neurosci 78:35-40. CrossRef Medline

Hong S, Zheng G, Wiley JW (2015) Epigenetic regulation of genes that modulate chronic stress-induced visceral pain in the peripheral nervous system. Gastroenterology 148:148-157.e7. CrossRef Medline

Ignatov A, Hermans-Borgmeyer I, Schaller HC (2004) Cloning and characterization of a novel G-protein-coupled receptor with homology to galanin receptors. Neuropharmacology 46:1114-1120. CrossRef Medline

Imai S, Ikegami D, Yamashita A, Shimizu T, Narita M, Niikura K, Furuya M, Kobayashi Y, Miyashita K, Okutsu D, Kato A, Nakamura A, Araki A, Omi K, Nakamura M, James Okano H, Okano H, Ando T, Takeshima H, Ushijima T, et al. (2013) Epigenetic transcriptional activation of monocyte chemotactic protein 3 contributes to long-lasting neuropathic pain. Brain 136:828-843. CrossRef Medline

Jaenisch R, Bird A (2003) Epigenetic regulation of gene expression: how the genome integrates intrinsic and environmental signals. Nat Genet 33: 245-254. CrossRef Medline

Jiang BC, Sun WX, He LN, Cao DL, Zhang ZJ, Gao YJ (2015) Identification of lncRNA expression profile in the spinal cord of mice following spinal nerve ligation-induced neuropathic pain. Mol Pain 11:43. CrossRef Medline 
Jiang BC, Cao DL, Zhang X, Zhang ZJ, He LN, Li CH, Zhang WW, Wu XB, Berta T, Ji RR, Gao YJ (2016) CXCL13 drives spinal astrocyte activation and neuropathic pain via CXCR5. J Clin Invest 126:745. CrossRef Medline

Jiang BC, He LN, Wu XB, Shi H, Zhang WW, Zhang ZJ, Cao DL, Li CH, Gu J, Gao YJ (2017) Promoted interaction of C/EBP alpha with demethylated $\mathrm{Cxcr} 3$ gene promoter contributes to neuropathic pain in mice. J Neurosci 37:685-700. CrossRef Medline

Ji RR, Gereau RW 4th, Malcangio M, Strichartz GR (2009) MAP kinase and pain. Brain Res Rev 60:135-148. CrossRef Medline

Jin SX, Zhuang ZY, Woolf CJ, Ji RR (2003) p38 Mitogen-activated protein kinase is activated after a spinal nerve ligation in spinal cord microglia and dorsal root ganglion neurons and contributes to the generation of neuropathic pain. J Neurosci 23:4017-4022. CrossRef Medline

Jurkowska RZ, Jurkowski TP, Jeltsch A (2011) Structure and function of mammalian DNA methyltransferases. Chembiochem 12:206-222. CrossRef Medline

Khrimian L, Obri A, Ramos-Brossier M, Rousseaud A, Moriceau S, Nicot AS, Mera P, Kosmidis S, Karnavas T, Saudou F, Gao XB, Oury F, Kandel E, Karsenty G (2017) Gpr158 mediates osteocalcin's regulation of cognition. J Exp Med 214:2859-2873. CrossRef Medline

Kobayashi Y, Sano Y, Vannoni E, Goto H, Suzuki H, Oba A, Kawasaki H, Kanba S, Lipp HP, Murphy NP, Wolfer DP, Itohara S (2013) Genetic dissection of medial habenula-interpeduncular nucleus pathway function in mice. Front Behav Neurosci 7:17. CrossRef Medline

Kojima T, Manabe I, Nagai R, Komuro I (2013) SUMOylation of KLF5 controls food intake by suppressing AgRP expression on contact with FoxO1 in hypothalamic neurons. Eur Heart J 34:780. CrossRef

Lacroix-Fralish ML, Ledoux JB, Mogil JS (2007) The pain genes database: an interactive web browser of pain-related transgenic knockout studies. Pain 131:3.e1-4. Medline

LaCroix-Fralish ML, Austin JS, Zheng FY, Levitin DJ, Mogil JS (2011) Patterns of pain: meta-analysis of microarray studies of pain. Pain 152:18881898. CrossRef Medline

Laumet G, Garriga J, Chen SR, Zhang Y, Li DP, Smith TM, Dong Y, Jelinek J, Cesaroni M, Issa JP, Pan HL (2015) G9a is essential for epigenetic silencing of $\mathrm{K}+$ channel genes in acute-to-chronic pain transition. Nat Neurosci 18:1746-1755. CrossRef Medline

Lei L, Laub F, Lush M, Romero M, Zhou J, Luikart B, Klesse L, Ramirez F, Parada LF (2005) The zinc finger transcription factor Klf7 is required for TrkA gene expression and development of nociceptive sensory neurons. Gene Dev 19:1354-1364. CrossRef Medline

Li Z, Mao Y, Liang L, Wu S, Yuan J, Mo K, Cai W, Mao Q, Cao J, Bekker A, Zhang W, Tao YX (2017a) The transcription factor C/EBP $\beta$ in the dorsal root ganglion contributes to peripheral nerve trauma-induced nociceptive hypersensitivity. Sci Signal 10:eaam5345. CrossRef Medline

Li Z, Tseng PY, Tiwari V, Xu Q, He SQ, Wang Y, Zheng Q, Han L, Wu Z, Blobaum AL, Cui Y, Tiwari V, Sun S, Cheng Y, Huang-Lionnet JH, Geng Y, Xiao B, Peng J, Hopkins C, Raja SN, et al. (2017b) Targeting human mas-related $\mathrm{G}$ protein-coupled receptor X1 to inhibit persistent pain. Proc Natl Acad Sci U S A 114:E1996-E2005. CrossRef Medline

Liu H, Qiu H, Yang J, Ni J, Le W (2016) Chronic hypoxia facilitates Alzheimer's disease through demethylation of $\gamma$-secretase by downregulating DNA methyltransferase 3b. Alzheimers Dement 12:130-143. CrossRef Medline

Lou S, Duan B, Vong L, Lowell BB, Ma Q (2013) Runx1 controls terminal morphology and mechanosensitivity of VGLUT3-expressing C-mechanoreceptors. J Neurosci 33:870-882. CrossRef Medline

Lyko F (2018) The DNA methyltransferase family: a versatile toolkit for epigenetic regulation. Nat Rev Genetics 19:81-92. CrossRef Medline

Mamet J, Klukinov M, Harris S, Manning DC, Xie S, Pascual C, Taylor BK, Donahue RR, Yeomans DC (2017) Intrathecal administration of AYX2 DNA decoy produces a long-term pain treatment in rat models of chronic pain by inhibiting the KLF6, KLF9, and KLF15 transcription factors. Mol Pain 13:1744806917727917. CrossRef Medline

Masseck OA, Spoida K, Dalkara D, Maejima T, Rubelowski JM, Wallhorn L, Deneris ES, Herlitze S (2014) Vertebrate cone opsins enable sustained and highly sensitive rapid control of Gi/o signaling in anxiety circuitry. Neuron 81:1263-1273. CrossRef Medline

Masuda T, Iwamoto S, Yoshinaga R, Tozaki-Saitoh H, Nishiyama A, Mak TW, Tamura T, Tsuda M, Inoue K (2014) Transcription factor IRF5 drives P2X4R+-reactive microglia gating neuropathic pain. Nat Commun 5:3771. CrossRef Medline

Moore DL, Blackmore MG, Hu Y, Kaestner KH, Bixby JL, Lemmon VP, Goldberg JL (2009) KLF family members regulate intrinsic axon regeneration ability. Science 326:298-301. CrossRef Medline

Moore DL, Apara A, Goldberg JL (2011) Kruppel-like transcription factors in the nervous system: novel players in neurite outgrowth and axon regeneration. Mol Cell Neurosci 47:233-243. CrossRef Medline

Nicol LS, Dawes JM, La Russa F, Didangelos A, Clark AK, Gentry C, Grist J, Davies JB, Malcangio M, McMahon SB (2015) The role of G-protein receptor 84 in experimental neuropathic pain. J Neurosci 35:8959-8969. CrossRef Medline

Niederberger E, Resch E, Parnham MJ, Geisslinger G (2017) Drugging the pain epigenome. Nat Rev Neurol 13:434-447. CrossRef Medline

Poetsch AR, Plass C (2011) Transcriptional regulation by DNA methylation. Cancer Treat Rev 37:S8-S12. CrossRef Medline

Pollema-Mays SL, Centeno MV, Apkarian AV, Martina M (2014) Expression of DNA methyltransferases in adult dorsal root ganglia is cell-type specific and up regulated in a rodent model of neuropathic pain. Front Cell Neurosci 8:217. CrossRef Medline

Qi L, Huang C, Wu X, Tao Y, Yan J, Shi T, Cao C, Han L, Qiu M, Ma Q, Liu Z, Liu Y (2017) Hierarchical specification of pruriceptors by runtdomain transcription factor Runx1. J Neurosci 37:5549-5561. CrossRef Medline

Reinhold AK, Batti L, Bilbao D, Buness A, Rittner HL, Heppenstall PA (2015) Differential transcriptional profiling of damaged and intact adjacent dorsal root ganglia neurons in neuropathic pain. PloS one 10:e0123342. CrossRef Medline

Xie RG, Gao YJ, Park CK, Lu N, Luo C, Wang WT, Wu SX, Ji RR (2018) Spinal CCL2 promotes central sensitization, long-term potentiation, and inflammatory pain via CCR2: further insights into molecular, synaptic, and cellular mechanisms. Neurosci Bull 34:13-21. CrossRef Medline

Yanagi M, Hashimoto T, Kitamura N, Fukutake M, Komure O, Nishiguchi N, Kawamata T, Maeda K, Shirakawa O (2008) Expression of Kruppel-like factor 5 gene in human brain and association of the gene with the susceptibility to schizophrenia. Schizophr Res 100:291-301. CrossRef Medline

Yin K, Deuis JR, Lewis RJ, Vetter I (2016) Transcriptomic and behavioural characterisation of a mouse model of burn pain identify the cholecystokinin 2 receptor as an analgesic target. Mol Pain 12:1744806916665366. CrossRef Medline

Yu B, Zhang K, Milner JJ, Toma C, Chen R, Scott-Browne JP, Pereira RM, Crotty S, Chang JT, Pipkin ME, Wang W, Goldrath AW (2017) Epigenetic landscapes reveal transcription factors that regulate $\mathrm{CD} 8(+) \mathrm{T}$ cell differentiation. Nat Immunol 18:573-582. CrossRef Medline

Zeilhofer HU, Wildner H, Yévenes GE (2012) Fast synaptic inhibition in spinal sensory processing and pain control. Physiol Rev 92:193-235. CrossRef Medline

Zhang HH, Hu J, Zhou YL, Qin X, Song ZY, Yang PP, Hu S, Jiang X, Xu GY (2015) Promoted interaction of nuclear factor- $\kappa \mathrm{B}$ with demethylated purinergic $\mathrm{P} 2 \mathrm{X} 3$ receptor gene contributes to neuropathic pain in rats with diabetes. Diabetes 64:4272-4284. CrossRef Medline

Zhang Z, Cai YQ, Zou F, Bie B, Pan ZZ (2011) Epigenetic suppression of GAD65 expression mediates persistent pain. Nat Med 17:1448-1455. CrossRef Medline

Zhao JY, Liang L, Gu X, Li Z, Wu S, Sun L, Atianjoh FE, Feng J, Mo K, Jia S, Lutz BM, Bekker A, Nestler EJ, Tao YX (2017) DNA methyltransferase DNMT3a contributes to neuropathic pain by repressing Kcna2 in primary afferent neurons. Nat Commun 8:14712. CrossRef Medline

Zhou YL, Jiang GQ, Wei J, Zhang HH, Chen W, Zhu H, Hu S, Jiang X, Xu GY (2015) Enhanced binding capability of nuclear factor- $\kappa$ B with demethylated P2X3 receptor gene contributes to cancer pain in rats. Pain 156: 1892-1905. CrossRef Medline

Zhuang ZY, Gerner P, Woolf CJ, Ji RR (2005) ERK is sequentially activated in neurons, microglia, and astrocytes by spinal nerve ligation and contributes to mechanical allodynia in this neuropathic pain model. Pain 114: 149-159. CrossRef Medline

Zhuang ZY, Wen YR, Zhang DR, Borsello T, Bonny C, Strichartz GR, Decosterd I, Ji RR (2006) A peptide c-jun N-terminal kinase (JNK) inhibitor blocks mechanical allodynia after spinal nerve ligation: respective roles of JNK activation in primary sensory neurons and spinal astrocytes for neuropathic pain development and maintenance. J Neurosci 26:35513560. CrossRef Medline 